\title{
Article \\ The Content and Sources of Potentially Toxic Elements in the Road Dust of Surgut (Russia)
}

\author{
Dmitriy Moskovchenko ${ }^{1,2, * \mathbb{C}}$, Roman Pozhitkov ${ }^{1}$, Andrey Soromotin ${ }^{2}$ and Valeriy Tyurin ${ }^{3}$ \\ 1 Tyumen Scientific Centre, Siberian Branch of Russian Academy of Sciences, 625026 Tyumen, Russia; \\ pozhitkov-roma@yandex.ru \\ 2 Institute of Earth Sciences, Tyumen State University, 625003 Tyumen, Russia; asoromotin@mail.ru \\ 3 Institute of Natural and Technical Sciences, Surgut State University, 628412 Surgut, Russia; tyurin_vn@mail.ru \\ * Correspondence: moskovchenko1965@gmail.com; Tel.: +7-922-488-32-11
}

check for

updates

Citation: Moskovchenko, D.;

Pozhitkov, R.; Soromotin, A.; Tyurin,

V. The Content and Sources of

Potentially Toxic Elements in the

Road Dust of Surgut (Russia).

Atmosphere 2022, 13, 30. https://

doi.org/10.3390/atmos13010030

Academic Editors: Dmitry Vlasov,

Omar Ramírez Hernández and

Ashok Luhar

Received: 19 November 2021

Accepted: 23 December 2021

Published: 26 December 2021

Publisher's Note: MDPI stays neutral with regard to jurisdictional claims in published maps and institutional affiliations.

Copyright: (c) 2021 by the authors Licensee MDPI, Basel, Switzerland. This article is an open access article distributed under the terms and conditions of the Creative Commons Attribution (CC BY) license (https:// creativecommons.org/licenses/by/ $4.0 /)$.

\begin{abstract}
The chemical and particle size composition of road dust in Surgut, which is a rapidly developing city in Western Siberia, was studied for the first time. Contents of major and trace elements were determined using ICP-MS and ICP-AES, respectively. It was found that the road dust had an alkaline $\mathrm{pH}$ (from 7.54 to 9.38) and that the particle size composition was dominated by the 100-250- $\mu \mathrm{m}$ fraction. The contamination assessment based on calculations of the enrichment factor $(E F)$ showed that the road dust was significantly enriched in $\mathrm{Sb}$ and $\mathrm{Cu}$ and moderately enriched in $\mathrm{Zn}, \mathrm{Pb}, \mathrm{Mo}, \mathrm{Ni}$ and $\mathrm{W}$. The sources of these elements are probably associated with the abrasion of car tires and brake pads. Based on calculations of global pollution index (PIr) and total enrichment factor $(\mathrm{Ze})$, the road dust of Surgut was characterized by a generally low level of potential ecological risk, except for stretches of road subject to regular traffic jams, where a moderate ecological risk level was identified. In comparison to the other Russian cities (Moscow, Chelyabinsk, Tyumen, etc.) where studies of road dust composition have been carried out, Surgut had similar contents of $\mathrm{Cr}$ and $\mathrm{Cu}$ and relatively lower contents of $\mathrm{Sb}, \mathrm{Cd}, \mathrm{As}$ and $\mathrm{Pb}$.
\end{abstract}

Keywords: Western Siberia; urban pollution; road dust; potentially toxic elements; traffic-related contamination

\section{Introduction}

Road dust is currently one of the main materials used in assessments of the ecological state of urban and industrial environments. Studies on road dust composition help to assess the total accumulation of pollutants from the atmosphere, soils and technogenic sources and to forecast the effects of those pollutants on human health. The advantages of using road dust in such assessments include its ease of sampling, ubiquity and non-point source nature, as well as its strong relationship with car exhaust emissions [1].

The road dust deposited within transport zones is regarded as a multicomponent mixture of different fractions that are formed as a result of soil erosion, abrasion of road surfaces and vehicle parts, incomplete combustion of fuel, application of de-icing agents, etc. [2-5]. Particles of road dust can accumulate many potentially toxic metals, metalloids and organic compounds [6-9]. The deposition rates of road dust and its chemical composition depend on factors such as vehicle emissions; abrasion of road tarmac, road markings, car tires and brake pads; and the corrosion of metal parts of vehicles, as well as traffic densities, speed and frequencies of car maneuvers such as braking and stopping [10-12]. At the same time, resuspended particles can be one of the most important sources of microparticles in the atmosphere [13]. The high concentration of harmful substances in the dust makes it hazardous to human health. Microparticles can be lifted by air currents and inhaled by humans and, therefore, increase the risks of respiratory, cardiovascular and oncological diseases [14]. Globally, road dust is a major source of inhalable particulate matter in any urban environment [15]. 
According to the Russian Federal Service for State Statistics, 75\% of the country's population live in cities [16]. Numerous studies have reported that transport-related air pollution is one of the dominant sources of urban air pollution and is a continuously contributing emission [17-19]. In many cities of Russia, numerous dangerous environmental situations resulting from atmospheric air pollution have been repeatedly noted [20,21]. Therefore, ecological assessments of such cities are highly important for providing comfortable and safe conditions for their residents. However, the majority of such assessments are conducted in large cities, with a lack of attention given to medium-sized and smaller cities.

There have been few studies on road dust within the territory of the former Soviet Union. Determinations of road dust composition have been carried out in Moscow [13,22-26], cities of the Perm Region [27], Chelyabinsk [20] and Alushta [28]. In Tyumen (West Siberia), Konstantinova et al. [29] have analyzed 20 samples of road dust, which were found to have high concentrations of $\mathrm{Cr}, \mathrm{Ni}$ and $\mathrm{Co}$.

Surgut has one of the highest concentrations of motorized vehicles in Russia, with about 200,000 vehicles registered within this city. Busy highways running through Surgut connect different cities and numerous oil fields of Western Siberia. There is also a railway running across Surgut. The city streets and roads have a total length of $266.7 \mathrm{~km}$, which corresponds to about $10 \%$ of the total area of urban constructions [30]. Such a high intensity of traffic has negative effects on the health of Surgut residents, in particular elevating the risks of cancer [31]. Traffic densities within the city drastically increase during certain peak hours of the mornings and evenings, when the traffic becomes very heavy and moves at an average speed of less than $10 \mathrm{~km}$ per hour. Nevertheless, the impacts of such traffic on the content of trace elements, including potentially toxic elements (PTEs), within the road dust of Surgut have not been studied until the present time. The objectives of this study were as follows: (i) to determine the total concentrations of major and trace elements, including PTEs, in the road dust of Surgut city, (ii) to assess the degree of contamination using contamination indices, (iii) to identify the potential sources of PTEs and (iv) to evaluate the human health risks of road dust.

\section{Materials and Methods}

\subsection{Study Area}

Surgut is located in the center of the West Siberian Plain, within the taiga zone. The climate is continental, with a mean annual temperature of $-1.8^{\circ} \mathrm{C}$ and a mean annual precipitation of $652 \mathrm{~mm}$ [32]. Southern and western winds prevail. The rapid development of Surgut began in the 1960s, following the discovery of numerous oil fields in the vicinities of the city. The population of Surgut grew from just over 6 thousand people in the early 1960s to 200 thousand in the mid-1980s and has reached nearly 400 thousand at the present time.

Surgut is one of the fastest growing cities in Russia. It is characterized by welldeveloped power engineering, food production, printing, building, publishing and sewing industries. Surgut's two largest gas-fired power stations, with a total output of 8.9 thousand MW, provide most of the regional power supply.

The ecological conditions of Surgut have been insufficiently studied, with only very few assessments within small areas. It has been found that the snowpack in Surgut is contaminated by heavy metals [33] and that $\mathrm{Pb}$ concentration in road-side soils exceeds its maximal permissible concentration [34]. Dumps of domestic and industrial waste also negatively affect the surrounding soils, where heavy metal concentrations exceed their maximal levels according to the ecological standards [35]. Moreover, there is a lack of data on the composition of the native soils of the Surgut region. It is only known that sandy soils with low contents of trace elements prevail within the Fedorovskoye Oil Field at distances of $20-50 \mathrm{~km}$ to the north of Surgut [36,37].

\subsection{Sampling and Laboratory Analyses}

Road dust sampling was undertaken in July 2021 during dry weather periods, i.e., no less than $36 \mathrm{~h}$ after any low-intensity rainfall. Samples of 200-300 g each were collected from 
road surfaces within $1 \times 1$ quadrats using a plastic brush and a scoop, placed into plastic bags and delivered to the laboratory. Sampling sites were located on roads with different traffic densities within different land use areas of the city. High, moderate and low traffic densities corresponded to $>2,1-2$ and $<1$ thousand cars per hour. The traffic data were sourced from the municipal program for the development of transport infrastructure in Surgut [30]. The different types of land use were recorded at the sampling sites as follows:

(1) Industrial and warehouse area.

(2) High-rise residential area.

(3) Low-rise residential area.

(4) Power plant area.

(5) Public and business area.

(6) Transport hubs (railway station and airport).

A total of 25 samples were taken. It has been shown that a relatively low number of samples (16-31) is sufficient for evaluating the level of pollution of road dust in cities with a medium population, e.g., Thessaloniki, Greece [38], Ma'an City, Jordan [39] and Sakaka city, Saudi Arabia [40]. Locations of the sampling sites are shown in Figure 1. A detailed description of the sampling sites is presented in Supplementary Materials, Table S1.

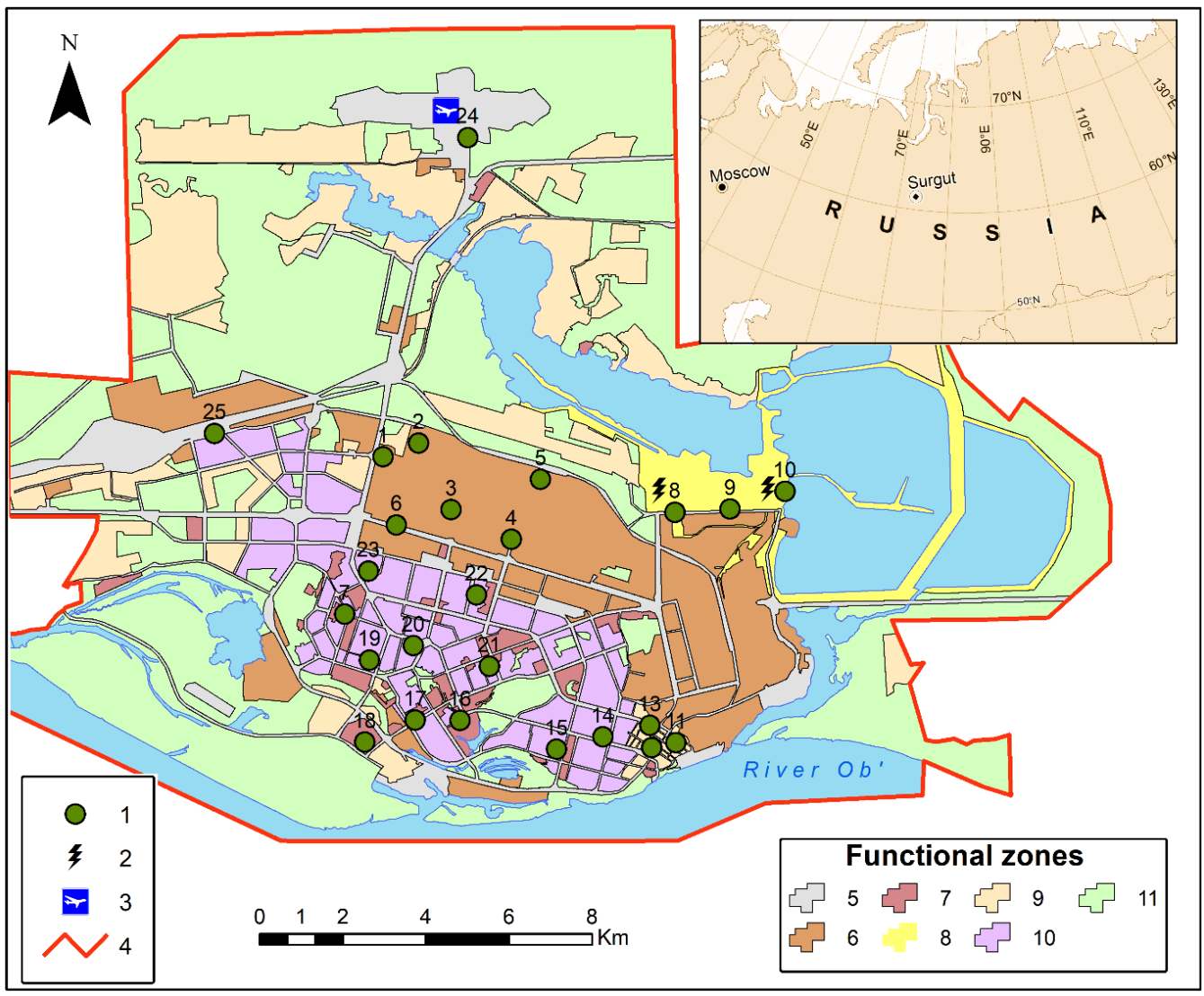

Figure 1. Sampling sites and land use areas within the city of Surgut: 1—sampling sites; 2 -power plants; 3-airport; 4-city border; 5-transport area; 6-industrial and warehouse area; 7-public and business area; 8- power plant area; 9-low-rise area; 10-high-rise residential area; 11-recreation area, urban forests, green spaces.

In the laboratory, the samples were passed through a sieve with an aperture of $1 \mathrm{~mm}$ in order to remove coarse inclusions (fragments of plants, rubbish, etc.). Although the pollutant concentrations in fine fractions (PM1 and PM10) of road dust are known to be higher than those in coarse fractions [13], we analyzed bulk samples in order to be able to compare our results from Surgut with the data from other cities. Bulk samples have been 
used in the majority of studies on road dust composition, whereas fine fractions have been separately analyzed in only a few studies $[7,13,26,41]$.

The $\mathrm{pH}$ values were measured potentiometrically in continuously mixed 1:2.5 dust:water suspensions using a Starter3100 conductivity meter (OHAUS, Baden-Wuerttemberg, Germany). The particle size distribution was determined using a Mastersizer 3000 laser diffraction particle size analyzer. Concentrations of 54 trace elements $(\mathrm{Li}, \mathrm{Be}, \mathrm{Sc}, \mathrm{V}, \mathrm{Cr}, \mathrm{Co}$, $\mathrm{Ni}, \mathrm{Cu}, \mathrm{Zn}, \mathrm{Ga}, \mathrm{As}, \mathrm{Se}, \mathrm{Rb}, \mathrm{Sr}, \mathrm{Y}, \mathrm{Zr}, \mathrm{Nb}, \mathrm{Mo}, \mathrm{Rh}, \mathrm{Pd}, \mathrm{Ag}, \mathrm{Cd}, \mathrm{Sn}, \mathrm{Sb}, \mathrm{Te}, \mathrm{Cs}, \mathrm{Ba}, \mathrm{La}, \mathrm{Ce}$, $\mathrm{Pr}, \mathrm{Nd}, \mathrm{Sm}, \mathrm{Eu}, \mathrm{Gd}, \mathrm{Tb}, \mathrm{Dy}, \mathrm{Ho}, \mathrm{Er}, \mathrm{Tm}, \mathrm{Yb}, \mathrm{Lu}, \mathrm{Hf}, \mathrm{Ta}, \mathrm{W}, \mathrm{Re}, \mathrm{Ir}, \mathrm{Pt}, \mathrm{Au}, \mathrm{Hg}, \mathrm{Tl}, \mathrm{Pb}, \mathrm{Bi}$, Th, $\mathrm{U})$ and 8 major elements in weight percent oxide for the particulate fraction $\left(\mathrm{Na}_{2} \mathrm{O}\right.$, $\mathrm{MgO}, \mathrm{Al}_{2} \mathrm{O}_{3}, \mathrm{P}_{2} \mathrm{O}_{5}, \mathrm{~S}, \mathrm{~K} 2 \mathrm{O}, \mathrm{CaO}, \mathrm{Fe}_{2} \mathrm{O}_{3}$ ) were measured by inductively coupled plasma mass spectrometry (ICP-MS) (Thermo Elemental-X7 spectrometer, Omaha, NE, USA) and inductively coupled plasma atom emission spectrometry (ICP-AES) (Thermo Scientific iCAP-6500 spectrometer, Thermo Fisher Scientific, Waltham, MA, USA), respectively. The analyzed samples, $100 \mathrm{mg}$ each, were prepared by acid digestion in an open beaker system. The samples were placed in Teflon beakers (volume $50 \mathrm{~mL}$ ); $0.1 \mathrm{~mL}$ of a solution containing $8 \mu \mathrm{g} \mathrm{dm}^{-3} 145 \mathrm{Nd}, 61 \mathrm{Dy}$ and $174 \mathrm{Yb}$ was added (control of the chemical yield during the sample decomposition procedure); and the mixture was moistened with several drops of deionized water. Then, $0.5 \mathrm{~mL}$ of $\mathrm{HClO}_{4}$ (perchloric acid fuming $70 \%$ Supratur, Merck), $3 \mathrm{~mL}$ of HF (hydrofluoric acid $40 \%$ GR, ISO, Merck KGaA, Darmstadt, Germany) and $0.5 \mathrm{~mL}$ of $\mathrm{HNO}_{3}$ (nitric acid $65 \%$, max. $0.0000005 \% \%$ GR, ISO, Merck) were added and evaporated until intense white vapors appeared. The beakers were cooled, their walls were washed with water and the solution was again evaporated to wet salts. Then, $2 \mathrm{~mL}$ of $\mathrm{HCl}$ (hydrochloric acid fuming 37\% OR, ISO, Merck KGaA, Darmstadt, Germany) and $0.2 \mathrm{~mL}$ of $0.1 \mathrm{M} \mathrm{H}_{3} \mathrm{BO}_{3}$ solution (analytical grade) were added and evaporated to a volume of $0.5-0.7 \mathrm{~mL}$. The resulting solutions were transferred into polyethylene bottles, $0.1 \mathrm{~mL}$ of a solution containing $10 \mathrm{mg} \mathrm{L}^{-1}$ In (internal standard) was added, diluted with deionized water to $20 \mathrm{~mL}$ and analysis was performed.

In addition to the studied samples, measurements were also taken for the blank and reference samples. We used the certified reference materials for soils-Gabbro Essexit STD-2A (GSO 8670-2005) and Andesite AGV-2 (United States Geological Survey) -in order to verify the accuracy of determinations. The comparison with the standard samples showed a sufficient repeatability (85-115\%) for the majority of the analyzed elements, except for Sn (59\%), Ba (70\%), Ag (153\%), Mo (78\%) and W (63\%), the measurements of which were excluded from the calculations. The analysis was performed in the Institute of Microelectronics Technology and High Purity Materials (Russian Academy of Sciences). The methods, recoveries, detection limits (DLs) and analytical results of the certified reference materials are given in the Supplementary Materials (Table S2).

\subsection{Calculations and Data Processing}

The processing of the statistical data was performed using Statistica 10.0 software (TIBCO, Palo Alto, CA, USA). Statistical parameters of the road dust composition (mean, standard deviation, maximum and minimum values) were determined. The significance of differences between the mean values for roads with different traffic intensities was assessed using the Mann-Whitney test.

Assessments carried out by two or more methods can improve the accuracy of the assessment result [42]. Therefore, to improve the accuracy of the result and make the assessment more comprehensive and systematic, additional methods were applied. Assessments of road dust contamination levels were based on calculations of generally accepted indices, including the global pollution index (PIr), enrichment factor $(E F)$ and potential ecological risk index $\left(E_{r}^{i}\right)$, as well as the total potential ecological risk index $(R I)$ and total enrichment factor $(Z e)$, the latter being commonly used in Russia.

The values of PIr were calculated using the following equation:

$$
\operatorname{PIr}=\mathrm{Cr} / \mathrm{K},
$$


where $\mathrm{Cr}$ is the concentration of an element in road dust and $\mathrm{K}$ is the concentration of the same element in the upper continental crust [13].

The $E F$ of an element, which is an important parameter for evaluating the contribution of human impact to its enrichment, is the normalization of a measured element against a reference element in a studied sample [43]. The $E F$ was calculated according to the equation:

$$
E F=\frac{C x}{C A l}(\text { sample }) / \frac{C x}{C A l}(\text { crust }),
$$

where $C x$ (sample) is the measured concentration of the element of interest, $C x$ (crust) is the concentration of the same element in the Earth's crust and $C A l$ is the concentration of the reference element (aluminum) in the same sample or the Earth's crust. Aluminum is most commonly used for calculations of $E F$ [44-46]. The low mobility and crustal abundance of $\mathrm{Al}$ makes it a suitable reference element. The composition of the upper continental crust was used as a reference for normalization because of the lack of a background analogue for road dust, which is a specific anthropogenic object [13]. The same method of calculation was applied in the other Russian cities studied [13,20,24,26,28]. The use of world average values in the continental crust is acceptable only within regions where there are no geochemical anomalies associated with the features of the geological structure. In this case, the element contents of soils, which are the source of particles in the atmosphere, are close to continental crust values. According to the scientific research on the contents of some heavy metals and metalloids in Western Siberia soils $[47,48]$, they are not very different from continental crust values. Indeed, the average contents of the elements in the soils of Western Siberia are as follows $\left(\mathrm{mg} \mathrm{kg}^{-1}\right)$ : $\mathrm{Co}-13, \mathrm{Cr}-84, \mathrm{Cu}-31, \mathrm{Ni}-42, \mathrm{~Pb}-18$, $\mathrm{Zn}-73$ and $\mathrm{Zr}-295$ [47]. These values are quite close to continental crust values according to Rudnick and Gao [49]. Therefore, comparisons with the distribution of elements in the Earth's crust are considered reasonable.

The potential ecological risk index $E_{r}^{i}$, which characterizes the degree of the ecological risk of a single element [50], was calculated by using the following equation:

$$
E_{r}^{i}=P I r \cdot T_{r}^{i}
$$

where PIr is the global pollution index and $T_{r}^{i}$ is the toxicity response coefficient. This index provides for the probability assessment of adverse ecological effects caused by exposure by to one or more pollutants [44]. In this study, we used the response $T_{r}^{i}$ values according to [50] as follows: $\mathrm{Zn}, \mathrm{Mn}, \mathrm{Fe}, \mathrm{W}, \mathrm{Sr}=1 ; \mathrm{Cr}, \mathrm{Mo}, \mathrm{Sn}, \mathrm{Sb}=2 ; \mathrm{Pb}, \mathrm{Cu}, \mathrm{Co}, \mathrm{Ni}=5 ; \mathrm{As}=10$ and $\mathrm{Cd}=30$. For risk assessments, we adopted the following gradation: $E_{r}^{i} \mathrm{i}<40$ describes low risk; $40<E_{r}^{i}<80$ indicates moderate risk; $80<E_{r}^{i}<160$ indicates considerable risk; $160<E_{r}^{i}<320$ indicates high risk; and $E_{r}^{i}>320$ indicates extreme risk [50,51].

The total rate of accumulation of PTEs and other chemical elements was estimated using two indices, the total potential ecological risk index $(R I)$ and the total enrichment factor $(\mathrm{Ze})$, because the use of different indices provides for the most accurate assessment of the ecological situation. The RI index, which characterizes the overall degree of the ecological risk of all metals under investigation [50], was calculated according to equation:

$$
R I=\sum E_{r}^{i}
$$

where $E_{r}^{i}$ is a potential ecological risk index of a single element. Risk levels were graded as follows: $R I<150$, low; $150<R I<300$, moderate; $300<R I<600$, considerable and $R I>600$, high ecological risk.

The values $Z e$ were calculated using the following equation:

$$
Z e=\sum E F-(n-1)
$$

where $E F$ of $n$ elements with $E F>1.5$ were summed up [24].

Criteria for assessment of road dust contamination are presented in Table 1. 
Table 1. Grades of enrichment factor $(E F)$, potential ecological risk index $\left(E_{r}^{i}\right)$, total potential ecological risk index $(R I)$ and total enrichment factor $(Z e)$.

\begin{tabular}{|c|c|c|c|c|c|c|c|}
\hline \multicolumn{2}{|c|}{ Enrichment Factor } & \multicolumn{2}{|c|}{ Potential Ecological Risk Index } & \multicolumn{2}{|c|}{$\begin{array}{l}\text { Total Potential } \\
\text { Ecological Risk Index }\end{array}$} & \multicolumn{2}{|c|}{ Total Enrichment Factor } \\
\hline$E F$ values & $\begin{array}{l}\text { Enrichment } \\
\text { level [1] }\end{array}$ & & $E_{r}^{i}$ grades $[50]$ & $\begin{array}{c}R I \\
\text { values }\end{array}$ & $R I$ levels [50] & Ze values & $\begin{array}{c}\text { Environmental } \\
\text { hazards }[13,25,26]\end{array}$ \\
\hline$E F \leq 2$ & Minimal & $E_{r}^{i}<40$ & Low & $R I<150$ & Low & $<32$ & Non-hazardous \\
\hline $2<E F \leq 5$ & Moderate & $40<E_{r}^{i}<80$ & Moderate & $150 \leq R I<300$ & Moderate & $32-64$ & $\begin{array}{c}\text { Moderately } \\
\text { dangerous }\end{array}$ \\
\hline $5<E F \leq 20$ & Significant & $80<E_{r}^{i}<160$ & Considerable & $200 \leq R I<600$ & High & $64-128$ & Dangerous \\
\hline $20<E F \leq 40$ & Very High & $160<E_{r}^{i}<320$ & High & $R \bar{I} \geq 600$ & Very High & $128-256$ & Very dangerous \\
\hline
\end{tabular}

Varimax-rotated principal component analysis (PCA) was applied to investigate the sources of PTEs. PCA is widely used to reduce data and to extract a small number of latent factors (principal components, PCs) for analyzing relationships among the observed variables [52].

The influence of road dust on the health of the Surgut population was evaluated using the U.S. Environmental Protection Agency (EPA) human health evaluation method [53]. This method implies that dust can induce negative effects when it is assimilated by the human body in three different pathways-ingestion, inhalation and dermal contact. Carcinogenic and non-carcinogenic risks can be calculated by summing up the risks from the three exposure pathways.

The calculations of such risks were based on the average daily dose (ADD) of the total assimilation of a certain element in three different ways. The equations and parameter values used for the calculations are presented in Table S3. Following the ADD calculations, we conducted determinations of non-carcinogenic hazard quotient (HQ) and carcinogenic risk assessment (CRA) using the following equation:

$$
\mathrm{HQ}=\mathrm{ADD} / \mathrm{RfD},
$$

where reference dose $\mathrm{RfD}\left(\mathrm{mg} \mathrm{kg}^{-1}\right.$ day $^{-1}$ ) is an estimation of the maximum permissible risks to the human population through daily exposure with consideration of sensitive groups during their lifetime.

Hazard index (HI), the sum of HQ(Ing/Der/Inh), was used by us to estimate the health risk of different exposure pathways. HI values of $\leq 1$ indicate no adverse health effects and HI values $>1$ indicate possible adverse health effects [54].

For carcinogenic risk (CRA), the dose was multiplied by the corresponding slope factor (SF) to produce an estimate of cancer risk [55] as follows:

$$
\mathrm{CRA}=\mathrm{ADD} \text { ing, dermal, inh } \times \mathrm{SF}
$$

Total cancer risk (CRAsum) was calculated as the sum of CRA for three exposure pathways (ingestion, inhalation and dermal contact).

\section{Results}

\subsection{The $p H$ and Particle Size Distribution}

The analyzed dust had an alkaline reaction, with a $\mathrm{pH}$ ranging from 7.54 to 9.38 . The roads with low, moderate and high traffic densities were characterized by mean $\mathrm{pH}$ values of $8.04,7.80$ and 7.82 , respectively. The data on road dust $\mathrm{pH}$ in other cities of the world fall within generally the same range, between 7 and 9.5 [56-59]. The alkaline reaction of city road dust is explained by the presence of microparticles of building materials as well as different pollutants originating from vehicle exhaust emissions. Acidifying gaseous compounds (mainly nitrogen oxides) of car exhausts are removed by air currents, whereas alkaline particulate matter stays on the road surface. According to [34], the urban soils of 
Surgut have neutral and alkaline $\mathrm{pH}$ values, as opposed to acid background soils around the city.

The particle size distribution of road dust was characterized by the predominance of the $100-250-\mu \mathrm{m}$ size fraction (fine sand), which ranged from 19.5 to $50.1 \%$ with a mean of $39 \%$. The content of the $100-250-\mu \mathrm{m}$ size fraction (very fine sand) was significantly lower, with a mean of $14.4 \%$. Sand-sized particles $(>50 \mu \mathrm{m})$ composed between 45 and $95 \%$ of the total mass (with a mean of $82.5 \%$ ). The $2-10-\mu \mathrm{m}$ size fraction and the $10-50-\mu \mathrm{m}$ size fraction had mean contents of 3.2 and $13.8 \%$, respectively. The content of clay $(<2 \mu \mathrm{m})$ ranged from 0.1 to $2.5 \%$.

Sand (mainly fine sand) is known to be the predominant particle size fraction of road dust in many Russian cities. For example, in Chelyabinsk, which is not very far from Surgut, road dust is characterized by the predominance of particles from 30 to $300 \mu \mathrm{m}$ [21]. In Moscow, road dust has the following mean contents of fractions: PM1 $-1.8 \%$, PM10-12.8\%, $10-50-\mu \mathrm{m}$ size fraction $-16.3 \%$ and $>50 \mu \mathrm{m}$ size fraction $-69.1 \%$ [24]. The predominance of coarse particles in road dust has been reported from many cities of the world. For example, the urban sediments collected from Manchester were made up primarily of medium sandsized particles ranging in size from 200 to $300 \mu \mathrm{m}$ [60]. The $125-500-\mu \mathrm{m}$ fraction was prevalent in the road dust of Thessaloniki, Greece [38].

It is generally believed that the predominance of particles of $180-240 \mu \mathrm{m}$ in road dust is indicative of deposition of soil particles together with particles produced by the movement of vehicles, i.e., the abrasion of road surfaces, tires and metal parts of cars [61]. Smaller particles usually originate from industrial emissions [21]. It has been found that dust from metallurgical enterprises has a median particle size ranging from 1.0 to $200 \mathrm{~mm}$ and volumes of PM10 from 10 to $84 \%$ depending on the technological processes and the raw materials used [62]. Therefore, the composition of road dust from Surgut mainly resulted from the deposition of soil particles and particles produced by traffic, with only a low contribution of particles originating from industrial plants.

The distribution of fractions of road dust depending on traffic densities is shown in Table 2. The highest contents of PM10 particles, which are easily carried by winds and create the highest risks for human health, were observed on roads with moderate and high traffic densities. The lowest contents of fine particles combined with the predominance of sand were found on small roads with low traffic densities. However, such differences between the roads with different traffic intensities were only very small. The Mann-Whitney test showed that the differences between the mean values of contents of those particle size fractions were insignificant. The highest percentage $(26.5 \%)$ of fine $(<50 \mu \mathrm{m})$ particles was found within the public and business area, which is located in the southern part of Surgut (sampling sites 16-18, see Figure 1). Such a high content of fine particles can be explained by the predominance of fine-textured alluvial soils within that area.

\subsection{The Chemical Composition of Road Dust}

Summary statistics for the studied chemical element contents in the road dust of Surgut are presented in Table 3. The predominant major elements include $\mathrm{Al}_{2} \mathrm{O}_{3}$ (with a mean of $4.2 \%), \mathrm{CaO}(3.9 \%), \mathrm{MgO}(2.8 \%)$ and $\mathrm{Fe}_{2} \mathrm{O}_{3}(2.4 \%)$, with the other major elements having mean contents of $<1 \%$. The upper part of continental Earth's crust has a different descending order of major element concentrations: $\mathrm{Al}_{2} \mathrm{O}_{3}(15.4 \%), \mathrm{Fe}_{2} \mathrm{O}_{3}(5.0 \%), \mathrm{CaO}$ (3.6\%), $\mathrm{Na}_{2} \mathrm{O}(3.27 \%), \mathrm{K}_{2} \mathrm{O}(2.8 \%)$ and $\mathrm{MgO}(2.48 \%)$, according to [49]. In comparison with the latter, Surgut's road dust has relatively low contents of aluminum and iron but a relatively high content of magnesium.

The majority of trace elements in the road dust had lower contents as compared to those in the upper part of the continental Earth's crust, which was indicated by the PIr values (see Table 3). For example, the contents of $\mathrm{Li}, \mathrm{Be}, \mathrm{Ga}, \mathrm{As}, \mathrm{Rb}, \mathrm{Zr}, \mathrm{Nb}$, all rare earth elements, Th and U were 3-10 times as low as their Clarke numbers. Most PTEs (Hg, As, $\mathrm{Ni}, \mathrm{Cr}, \mathrm{Co}, \mathrm{V})$ do not accumulate in the road dust of Surgut. Such low contents of trace elements can be explained by the predominance of sand fractions and low contents of fine 
fractions in the particle size composition of the studied samples. It has been repeatedly shown that fine particles are most enriched in trace elements [63,64].

Relative enrichment as compared to the world average values in the Earth's continental crust was observed in $\mathrm{Sb}, \mathrm{Cu}, \mathrm{Zn}, \mathrm{Cd}$ and $\mathrm{Pb}$ (Table 3). The elements accumulated in Surgut's road dust can be defined as typical urban pollutants, including $\mathrm{Cd}, \mathrm{Pb}, \mathrm{Sb}, \mathrm{Ti}, \mathrm{Ba}$, $\mathrm{Zn}$ and, to a lesser degree, $\mathrm{Cu}$ [65-68]. A similar assemblage of pollutants ( $\mathrm{Sb}, \mathrm{Pb}, \mathrm{Zn}, \mathrm{Cd}$, $\mathrm{Cu}$ and $\mathrm{Sn}$ ) has been found in the road dust of Moscow [13].

Table 2. The percentage of particle size fractions $(\mathrm{mm})$ in road dust depending on (a) traffic densities and (b) land use within Surgut city.

\begin{tabular}{|c|c|c|c|c|c|c|c|}
\hline Area & $<0.002$ & $0.002-0.01$ & $0.01-0.05$ & $0.05-0.1$ & $0.1-0.25$ & $0.25-0.5$ & $0.5-1.0$ \\
\hline \multicolumn{8}{|c|}{ Traffic Densities: } \\
\hline Low $(\mathrm{n}=8)$ & $0.5 \pm 0.1^{1}$ & $2.6 \pm 0.7$ & $14.9 \pm 5.1$ & $14.6 \pm 6.7$ & $36.7 \pm 5.4$ & $26.1 \pm 7.4$ & $4.4 \pm 0.4$ \\
\hline Moderate $(n=14)$ & $0.7 \pm 0.7$ & $3.8 \pm 3.2$ & $14.0 \pm 8.5$ & $14.5 \pm 4.0$ & $40.0 \pm 6.9$ & $24.2 \pm 7.8$ & $2.7 \pm 1.9$ \\
\hline $\operatorname{High}(n=3)$ & $0.4 \pm 0.1$ & $2.1 \pm 0.7$ & $\begin{array}{l}12.0 \pm 5.1 \\
\text { Land use Areas }\end{array}$ & $15.0 \pm 6.7$ & $42.0 \pm 5.4$ & $26.2 \pm 7.6$ & $2.4 \pm 0.4$ \\
\hline $\begin{array}{l}\text { Industrial and warehouse } \\
\text { area }(\mathrm{n}=6)\end{array}$ & $0.25 \pm 0.3$ & $2.0 \pm 1.1$ & $8.9 \pm 3.6$ & $11.9 \pm 2.8$ & $44.4 \pm 3.4$ & $29.5 \pm 4.6$ & $3.1 \pm 1.4$ \\
\hline $\begin{array}{l}\text { High-rise residential area } \\
\qquad(\mathrm{n}=6)\end{array}$ & $0.5 \pm 0.32$ & $2.6 \pm 0.8$ & $13.2 \pm 5.7$ & $16.0 \pm 6.0$ & $39.0 \pm 5.0$ & $25.1 \pm 7.5$ & $3.5 \pm 1.9$ \\
\hline $\begin{array}{l}\text { Low-rise residential area } \\
\qquad(\mathrm{n}=5)\end{array}$ & $0.7 \pm 1.0$ & $4.4 \pm 5.0$ & $13.6 \pm 13.8$ & $12.2 \pm 5.3$ & $36.9 \pm 9.4$ & $27.1 \pm 12.2$ & $4.8 \pm 3.9$ \\
\hline Power plant area $(\mathrm{n}=3)$ & $0.9 \pm 0.7$ & $4.5 \pm 2.6$ & $14.5 \pm 7.5$ & $14.8 \pm 2.4$ & $39.3 \pm 4,2$ & $23.2 \pm 7.3$ & $3.1 \pm 2.6$ \\
\hline $\begin{array}{l}\text { Public and business area } \\
\qquad(\mathrm{n}=3)\end{array}$ & $0.9 \pm 0.6$ & $3.0 \pm 0.9$ & $26.5 \pm 13.4$ & $21.0 \pm 2.9$ & $31.0 \pm 9.4$ & $15.8 \pm 7.4$ & $1.9 \pm 0.9$ \\
\hline Transport hubs $(\mathrm{n}=2)$ & $0.7 \pm 0.2$ & $3.6 \pm 1.0$ & $10.8 \pm 5.8$ & $11.9 \pm 4.4$ & $43.8 \pm 3.4$ & $27.3 \pm 7.5$ & $2.0 \pm 0.6$ \\
\hline
\end{tabular}

${ }^{1}$ Mean \pm SD.

Table 3. Summary statistics for the contents of PTEs and other chemical elements in Surgut's road dust, $\mathrm{n}=25\left(\mathrm{Na}_{2} \mathrm{O}-\mathrm{Fe}_{2} \mathrm{O}_{3}\right.$ in \%, $\mathrm{Li}-\mathrm{U}$ in $\left.\mathrm{mg} \mathrm{kg}^{-1}\right)$.

\begin{tabular}{ccccccccc}
\hline Element & DL & Mean & Sd & Min & Max & V, \% & WA & PIr \\
\hline $\mathrm{Al}_{2} \mathrm{O}_{3}$ & 0.009 & 4.2 & 0.97 & 2.6 & 6.68 & 23 & 15.4 & $0.3(0.2-0.4)$ \\
$\mathrm{CaO}$ & 0.005 & 3.9 & 1.42 & 2.0 & 7.81 & 36 & 3.59 & $1.1(0.5-2.2)$ \\
$\mathrm{Fe}_{2} \mathrm{O}_{3}$ & 0.01 & 2.4 & 0.60 & 1.2 & 3.86 & 25 & 5.04 & $0.5(0.2-0.8)$ \\
$\mathrm{K}_{2} \mathrm{O}$ & 0.002 & 0.80 & 0.16 & 0.55 & 1.26 & 20 & 2.8 & $0.3(0.2-0.5)$ \\
$\mathrm{MgO}$ & 0.005 & 2.8 & 1.06 & 1.4 & 5.48 & 37 & 2.48 & $1.1(0.5-2.2)$ \\
$\mathrm{MnO}$ & 0.0004 & 0.043 & 0.013 & 0.024 & 0.071 & 29 & 0.1 & $0.4(0.2-0.7)$ \\
$\mathrm{Na}_{2} \mathrm{O}$ & 0.001 & 0.91 & 0.22 & 0.65 & 1.48 & 24 & 3.27 & $0.3(0.2-0.5)$ \\
$\mathrm{P}_{2} \mathrm{O}_{5}$ & 0.005 & 0.06 & 0.03 & 0.025 & 0.15 & 58 & 0.15 & $0.4(0.2-1.0)$ \\
$\mathrm{S}$ & 0.002 & 0.064 & 0.021 & 0.028 & 0.12 & 33 & 0.062 & $1.0(0.4-2.0)$ \\
$\mathrm{TiO}$ & 0.0005 & 0.27 & 0.09 & 0.12 & 0.55 & 35 & 0.64 & $0.4(0.2-0.9)$ \\
$\mathrm{As}$ & 0.1 & 1.29 & 0.65 & 0.4 & 3.3 & 51 & 4.8 & $0.3(0.1-0.7)$ \\
$\mathrm{Be}$ & 0.03 & 0.42 & 0.12 & 0.3 & 0.72 & 28 & 2.1 & $0.2(0.1-0.3)$ \\
$\mathrm{Bi}$ & 0.01 & 0.067 & 0.046 & 0.02 & 0.22 & 69 & 0.16 & $0.4(0.1-1.4)$ \\
$\mathrm{Cd}$ & 0.04 & 0.11 & 0.15 & 0.04 & 0.66 & 136 & 0.09 & $1.2(0.4-7.4)$ \\
$\mathrm{Ce}$ & 0.008 & 15.5 & 8.1 & 8.4 & 45.4 & 52 & 63 & $0.2(0.13-0.7)$ \\
$\mathrm{Co}$ & 0.08 & 6.9 & 1.7 & 3.8 & 11.2 & 25 & 17.3 & $0.4(0.2-0.7)$ \\
$\mathrm{Cr}$ & 0.7 & 46.4 & 15.4 & 18.4 & 83.9 & 33 & 92 & $0.5(0.2-0.9)$ \\
$\mathrm{Cs}$ & 0.01 & 0.43 & 0.17 & 0.24 & 1.0 & 39 & 4.9 & $0.1(0.05-0.2)$ \\
$\mathrm{Cu}$ & 0.8 & 42.8 & 27.3 & 9.3 & 144.9 & 64 & 28 & $1.5(0.3-5.2)$ \\
$\mathrm{Dy}$ & 0.007 & 1.12 & 0.44 & 0.74 & 2.59 & 39 & 3.9 & $0.3(0.2-0.7)$ \\
$\mathrm{Er}$ & 0.003 & 0.60 & 0.24 & 0.40 & 1.34 & 39 & 2.3 & 1 \\
$\mathrm{Eu}$ & 0.006 & 0.40 & 0.19 & 0.26 & 1.17 & 47 & $23(0.2-0.6)$ \\
$\mathrm{Ga}$ & 0.1 & 3.74 & 0.84 & 2.6 & 6.1 & 23 & 17.5 & $0.4(0.3-1.2)$ \\
$\mathrm{Gd}$ & 0.007 & 1.20 & 0.53 & 0.77 & 3.13 & 44 & 4 & $0.2(0.1-0.3)$ \\
& & & & & & $0.3(0.2-0.8)$ \\
\hline
\end{tabular}


Table 3. Cont.

\begin{tabular}{|c|c|c|c|c|c|c|c|c|}
\hline Element & DL & Mean & Sd & Min & Max & $\mathrm{V}, \%$ & WA & PIr \\
\hline Hf & 0.02 & 0.72 & 0.24 & 0.5 & 1.7 & 33 & 5.3 & $0.14(0.1-0.3)$ \\
\hline Ho & 0.005 & 0.21 & 0.08 & 0.13 & 0.48 & 40 & 0.83 & $0.2(0.2-0.6)$ \\
\hline $\mathrm{La}$ & 0.009 & 7.05 & 3.03 & 4.0 & 17.7 & 43 & 31 & $0.2(0.13-0.6)$ \\
\hline $\mathrm{Li}$ & 0.03 & 5.16 & 1.04 & 3.7 & 7.57 & 20 & 24 & $0.2(0.2-0.3)$ \\
\hline $\mathrm{Lu}$ & 0.005 & 0.091 & 0.035 & 0.06 & 0.20 & 39 & 0.31 & $0.3(0.2-0.6)$ \\
\hline $\mathrm{Nb}$ & 0.02 & 2.85 & 1.55 & 1.5 & 8.9 & 55 & 12 & $0.2(0.1-0.7)$ \\
\hline $\mathrm{Nd}$ & 0.009 & 6.78 & 3.83 & 3.86 & 22.5 & 56 & 27 & $0.3(0.14-0.8)$ \\
\hline $\mathrm{Ni}$ & 0.7 & 41.1 & 17.0 & 12.1 & 90.1 & 41 & 47 & $0.9(0.3-1.9)$ \\
\hline $\mathrm{Pb}$ & 0.06 & 19.0 & 25.5 & 5.6 & 126.1 & 134 & 17 & $1.1(0.3-7.4)$ \\
\hline $\operatorname{Pr}$ & 0.005 & 1.77 & 0.96 & 0.95 & 5.50 & 54 & 7.1 & $0.2(0.13-0.8)$ \\
\hline $\mathrm{Rb}$ & 0.1 & 19.8 & 4.21 & 13.0 & 33.3 & 21 & 84 & $0.2(0.2-0.4)$ \\
\hline $\mathrm{Sb}$ & 0.06 & 0.89 & 0.57 & 0.38 & 3.13 & 64 & 0.4 & $2.2(1.0-7.8)$ \\
\hline Sc & 0.09 & 5.62 & 1.30 & 3.7 & 8.5 & 23 & 14 & $0.4(0.3-0.6)$ \\
\hline Sm & 0.004 & 1.42 & 0.73 & 0.85 & 4.26 & 51 & 4.7 & $0.3(0.2-0.9)$ \\
\hline $\mathrm{Sr}$ & 0.07 & 119.6 & 27.8 & 91.0 & 210.6 & 23 & 320 & $0.4(0.3-0.7)$ \\
\hline $\mathrm{Ta}$ & 0.01 & 0.19 & 0.13 & 0.1 & 0.7 & 69 & 0.88 & $0.2(0.1-0.8)$ \\
\hline $\mathrm{Tb}$ & 0.004 & 0.18 & 0.08 & 0.12 & 0.48 & 44 & 0.7 & $0.3(0.2-0.7)$ \\
\hline Th & 0.01 & 1.45 & 0.65 & 0.7 & 3.2 & 45 & 10.5 & $0.1(0.07-0.3)$ \\
\hline $\mathrm{Tl}$ & 0.005 & 0.08 & 0.02 & 0.05 & 0.15 & 23 & 0.9 & $0.1(0.06-0.16)$ \\
\hline $\mathrm{Tm}$ & 0.004 & 0.086 & 0.034 & 0.06 & 0.20 & 40 & 0.3 & $0.3(0.2-0.7)$ \\
\hline $\mathrm{U}$ & 0.01 & 0.61 & 0.27 & 0.4 & 1.6 & 44 & 2.7 & $0.2(0.1-0.6)$ \\
\hline $\mathrm{V}$ & 0.8 & 42.1 & 11.9 & 20.6 & 67.6 & 28 & 97 & $0.4(0.2-0.7)$ \\
\hline $\mathrm{Y}$ & 0.02 & 6.03 & 2.29 & 4.1 & 13.2 & 38 & 21 & $0.3(0.2-0.6)$ \\
\hline $\mathrm{Yb}$ & 0.003 & 0.66 & 0.27 & 0.45 & 1.54 & 41 & 2 & $0.3(0.2-0.8)$ \\
\hline $\mathrm{Zn}$ & 0.5 & 89.9 & 50.6 & 35.6 & 262.7 & 56 & 67 & $1.3(0.5-3.9)$ \\
\hline $\mathrm{Zr}$ & 0.04 & 28.6 & 10.1 & 18.2 & 68.8 & 35 & 193 & $0.1(0.1-0.4)$ \\
\hline
\end{tabular}

Note: WA-world average [49]; $\mathrm{Se}, \mathrm{Rh}, \mathrm{Pd}, \mathrm{Te}, \mathrm{Re}, \mathrm{Ir}, \mathrm{Pt}, \mathrm{Hg}$ and $\mathrm{Au}$ contents were below their detection limits in $50 \%$ samples, and hence, they were excluded from calculations.

$\mathrm{The} \mathrm{Pb}, \mathrm{Cu}$ and $\mathrm{Zn}$ contents in the soils of Western Siberia are similar to world average values and occasionally even lower [47]. It has also been shown that the Sb content in soils in the north of Western Siberia is below its world average value [69]. Therefore, enrichment in those trace elements in the road dust of Surgut is connected with the impact of anthropogenic sources, which is indirectly confirmed by significant variations in $\mathrm{Cd}(\mathrm{CV}$ of $136 \%), \mathrm{Pb}(134 \%)$ and $\mathrm{Sb}(64 \%)$. Elements originating predominantly from natural sources are expected to have a relatively lower variability, while those from anthropogenic sources should display a greater variability [70,71]. Significant variations in PTE concentrations indicate significant contributions from anthropogenic sources and a spatial heterogeneity of human impacts on the roads [13]. In addition, such variations reflect differences in the rates of pollution depending on road traffic, industrial emissions and street cleaning.

It should be mentioned that dust particles separated from the snowpack within Western Siberia, including remote background areas, are enriched in $\mathrm{Sb}, \mathrm{Zn}, \mathrm{Cd}$ and $\mathrm{As}$ [72]. Therefore, the assemblage of air pollutants within Surgut city is similar to the region-scale assemblage of air pollutants, which is indicative of their broad distribution. It is likely that the composition of atmospheric particulate matter within Western Siberia is generally predetermined by emissions from different cities and other point sources, the specific contributions of which can only be assessed when a larger database on such sources is available, but at the present time it is impossible to provide such an assessment with sufficient reliability.

The mean $E F$ values of $S b$ (8.3) indicated significant enrichment. A very high level of enrichment $(20<E F<40)$ in both $\mathrm{Sb}$ and $\mathrm{Pb}$ was observed in only one sample, which was collected from a stretch of road with a high traffic intensity within the industrial and warehouse area. Such a combined $\mathrm{Sb}$ and $\mathrm{Pb}$ contamination of road dust can be explained by emissions of those elements from worn car batteries that were made with the use of $\mathrm{Sb}-\mathrm{Pb}$ alloys up until very recently [73]. 
Of the studied samples, $48 \%$ were significantly enriched in $\mathrm{Cu}, 32 \%$ in $\mathrm{Zn}, 20 \%$ in $\mathrm{Ni}, 12 \%$ in $\mathrm{Pb}$ and $4 \%$ in $\mathrm{Cd}$. The mean EF values of $\mathrm{Pb}(4.3), \mathrm{Ni}(3.3)$ and $36 \%$ EF of $\mathrm{Cr}$ were between 2 and 5, indicating moderate enrichment. Other trace elements were characterized by mean $E F$ values of $<2$, i.e., belonging to the category of "deficiency to minimal enrichment" according to [1].

The data obtained on the distribution of $E F, Z e$ and $R I$ values over the city territory depending on the land use areas and road traffic intensities are shown in Table 4 . The highest total contamination levels were observed in the industrial area and the roads with high traffic intensities (with the Ze values of 43 and 44 , respectively). There was a clear relationship between the contamination level and the traffic density.

Table 4. The values of enrichment factor $(E F)$, total potential ecological risk index $(R I)$ and total enrichment factor $(\mathrm{Ze})$ in the road dust of Surgut.

\begin{tabular}{|c|c|c|c|c|}
\hline \multirow{2}{*}{ Area } & \multicolumn{2}{|c|}{ Contamination Levels and EF Values } & \multirow[b]{2}{*}{$Z e$} & \multirow[b]{2}{*}{$R I$} \\
\hline & Significant $(E F=5-20)$ & Moderate $(E F=2-5)$ & & \\
\hline \multicolumn{5}{|l|}{ Land Use Areas } \\
\hline Industrial and warehouse area $(n=6)$ & $\mathrm{Sb} 12 \mathrm{~Pb} 9 \mathrm{Cu} 7$ & $\mathrm{Ni3}$ & 43 & 55 \\
\hline High-rise residential area $(n=6)$ & Cu 5 Zn 5 & $\mathrm{Ni} 3 \mathrm{~Pb} 2$ & 31 & 79 \\
\hline Low-rise residential area $(n=5)$ & $\mathrm{Sb} 6$ & Ni4 Cu4 Zn4 Cr2 & 27 & 47 \\
\hline Power plant area $(\mathrm{n}=3)$ & $\mathrm{Sb} 9$ & $\mathrm{Cu} 5 \mathrm{Zn} 5 \mathrm{Ni} 4 \mathrm{Cr} 2 \mathrm{~Pb} 2$ & 32 & 39 \\
\hline Public and business area $(n=3)$ & $\mathrm{Zn} 7 \mathrm{Cu} 6 \mathrm{Sb} 6$ & $\mathrm{~Pb} 2$ & 29 & 87 \\
\hline Transport hubs $(\mathrm{n}=2)$ & $\mathrm{Sb} 8$ & $\mathrm{Cu} 4 \mathrm{Ni} 3 \mathrm{Zn} 3 \mathrm{Fe} 2$ & 30 & 30 \\
\hline \multicolumn{5}{|l|}{ Traffic Density } \\
\hline Low $(\mathrm{n}=8)$ & $\mathrm{Sb} 5$ & $\mathrm{Cu} 4 \mathrm{Zn} 3 \mathrm{Ni} 3 \mathrm{~Pb} 2$ & 28 & 39 \\
\hline Moderate $(n=14)$ & Sb10 Cu 6 Pb 6 & Zn5 Ni3 & 40 & 53 \\
\hline $\operatorname{High}(\mathrm{n}=3)$ & Zn9 Sb8 Cu8 & $\mathrm{Ni} 4 \mathrm{~Pb} 3 \mathrm{Cd} 2$ & 44 & 144 \\
\hline Total for Surgut & Sb $8.1 \mathrm{Cu} 5.5$ & $\mathrm{Zn} 4.9 \mathrm{~Pb} 4 \mathrm{Ni} 4$ & 37 & 59 \\
\hline
\end{tabular}

Note: the numbers after the elements correspond to their mean $E F$ values. Elements with $E F<2$ are not shown.

The dust samples from roads with low traffic densities only had a significant enrichment in Sb. Roads with heavier traffic were characterized by dust enrichment in practically all pollutants, including $\mathrm{Sb}, \mathrm{Zn}, \mathrm{Cu}$ and $\mathrm{Pb}$. In particular, the roads with moderate and high traffic intensities as compared to the roads with low traffic intensities were characterized by the following increases in pollutant concentrations: $\mathrm{Zn}$ by multiples of 1.4-2.8, $\mathrm{Cu}-1.3-1.7$, $\mathrm{Pb}-1.1-2.5, \mathrm{Cd}-1.3-2.8, \mathrm{Sb}-1.5-1.9$ and Bi by multiples of 1.7-2.0. Verification using the Mann-Whitney test showed that small roads significantly differ from medium and large ones in the enrichment of road dust with $\mathrm{Zn}, \mathrm{Sb}$ and $\mathrm{Pb}(p=0.01)$. The dust samples from roads with low, moderate and high traffic densities were characterized the total enrichment factor $Z e$ values of 28, 40 and 44, respectively, with an overall mean of 37. As compared to Moscow, where the mean for $Z e$ is 54 [13], Surgut has a lower level of road dust contamination, which can be easily explained by Moscow's much higher intensities of traffic and industrial emissions, both being sources of PTEs. However, it should be taken into account that concentrations of some elements (Mo, W and Sn) were excluded from the calculations, and therefore, the index values could be slightly underestimated.

The spatial distribution of Ze values is shown in Figure 2. The highest values are found within the road stretches where traffic jams regularly occur, which causes the increase in emissions of fine particles and soot.

The total potential ecological risk index (RI) had values between 150 and 300 in only two samples, which corresponded to the category of "moderate risk" according to [50]. Those abnormal values resulted from a sporadic occurrence of high $\mathrm{Cd}$ concentrations in the road dust. The samples from business areas had high $\mathrm{Cd}$ concentrations $(0.33$ and $0.66 \mathrm{mg} \mathrm{kg}^{-1}$ ) as well as a high concentration of Zn. Solid waste incinerators are known to be an important source of both Cd and Zn [74]. It is likely that solid waste incineration was practiced near our sampling sites. In addition, car tire wear is also a source of Cd [75]. All 
other studied samples belonged to the category of low risk, with the maximal values of total potential ecological risk index RI found on roads with high traffic densities.

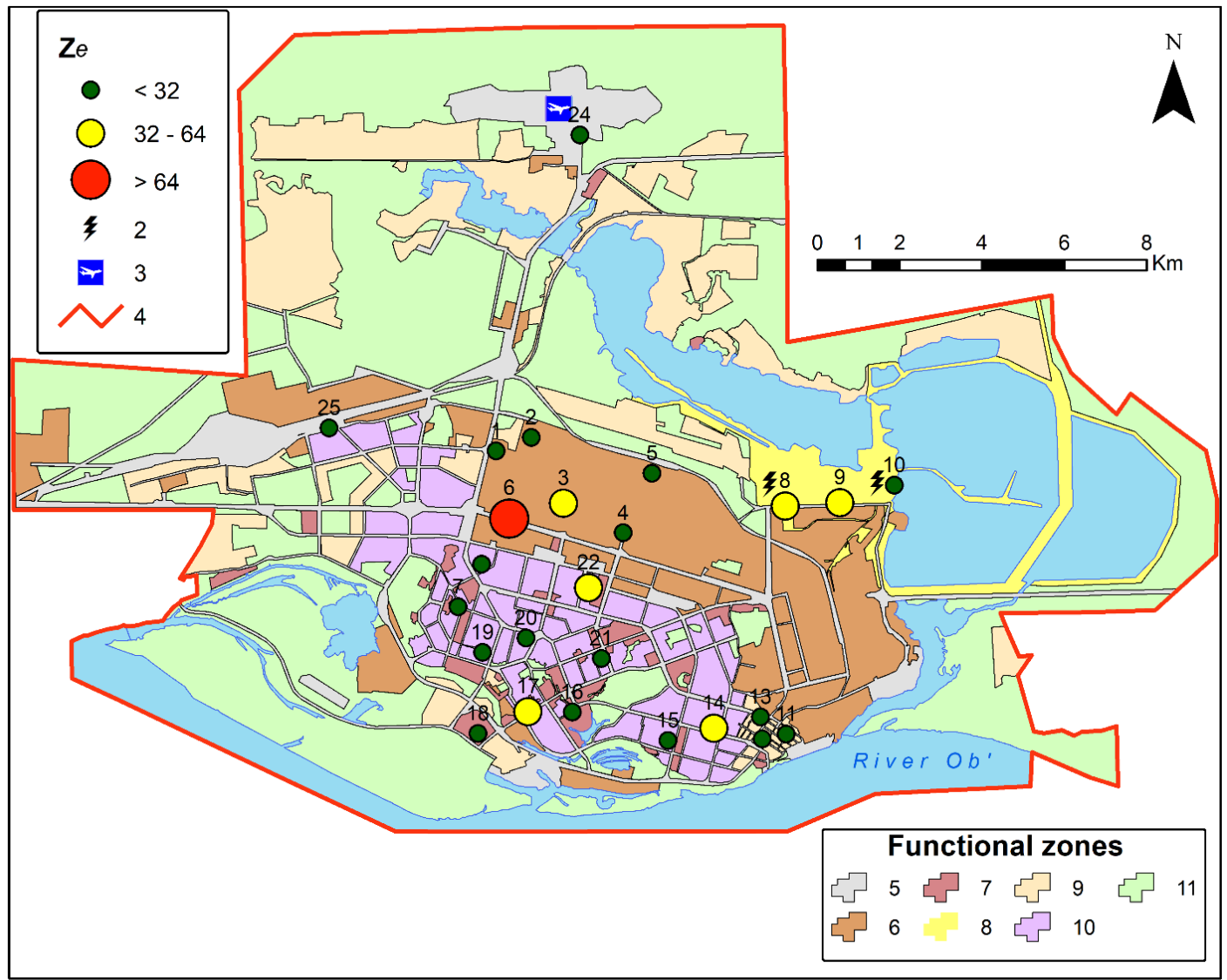

Figure 2. Spatial distribution of Ze values: 1-sampling sites; 2-power plants; 3-airport; 4-city border; 5-industrial and warehouse area; 6-high-rise residential area; 7-low-rise residential area; 8-power plant area; 9-public and business area; 10-modern business zones; 11-recreational area, urban forests, green spaces.

\subsection{Source Identification}

The most significant contributors to PTE pollution from vehicles are considered to be brake wear, tire erosion, exhaust emissions and oil losses [76]. The other source of PTEs, which include $\mathrm{V}, \mathrm{Cr}, \mathrm{Co}, \mathrm{Ni}, \mathrm{Cu}, \mathrm{Zn}$ and $\mathrm{Pb}$, is the abrasion of road tarmac [77,78]. Calculations of $E F$ values showed that $\mathrm{Sb}, \mathrm{Zn}, \mathrm{Mo}, \mathrm{Cu}$ and $\mathrm{Pb}$ were the main pollutants of Surgut's road dust (See Table 3). The main source of Sb in road dust is brake wear [79]. Antimony pentasulfide is used as a pigment in the production of car tires [80]. On the road stretches where traffic regularly slows and stops (traffic lights, cross-roads, etc.), $\mathrm{Sb}$ concentrations are generally eight times as high as those in the background [81]. Antimony is also used for the production of car batteries.

Tire erosion is also a source of $\mathrm{Zn}$, because zinc oxide is used as a vulcanization agent in tire production [78,82]. The concentration of $\mathrm{Zn}$ in car tires is about 1\% [77]. Research on the variability in the chemical composition of road dust in Spain by Amato et al. [7] has shown that contents of $\mathrm{Sb}, \mathrm{Zn}$ and Mo are increased within stretches of roads where traffic slows and stops, which confirms their relationship with tire wear.

Principal sources of $\mathrm{Cu}$ in the atmosphere include fossil fuel burning, traffic emissions, fuel combustion and industrial combustion [83]. The erosion of brake pads is an important source of $\mathrm{Cu}$ in road dust. It is known that up to $47 \%$ of $\mathrm{Cu}$ in urban sewage is also sourced from brake pad wear [84]. The degradation of brake pads over time contributes $\mathrm{Fe}, \mathrm{Cu}, \mathrm{Pb}$, $\mathrm{Cr}, \mathrm{Zn}$ and $\mathrm{Sb}$ to road dust [85]. 
It should be noted that $\mathrm{Cu}$ and $\mathrm{Zn}$ are the main PTE components within high-rise residential areas that have the highest number of traffic lights (see Figure 2). Traffic jams where vehicles move at a speed of $20 \mathrm{~km} / \mathrm{h}$ result in a $30 \%$ increase in car exhaust emissions [86]. Therefore, we believe that the high content of $\mathrm{Cu}$ in the road dust of Surgut mainly resulted from brake pad erosion.

To verify the sources of pollution, we conducted a PCA analysis of the obtained data set on the contents of PTEs, $\mathrm{pH}$ values and the content of fine particles $(<2$ and $2-10 \mu \mathrm{m})$. Elements of geogenic origin with concentrations similar to their world crust average were excluded from the analysis, which therefore included only the ecologically hazardous elements ( $\mathrm{Cr}, \mathrm{Co}, \mathrm{V}$, etc.). Our choice of the fine fraction was based on the fact that fine fractions have the highest PTE contents, e.g., the PM10 fraction of Moscow's road dust is 1.2-6.4 times more polluted by PTEs than bulk samples of the dust [13].

The essence of PCA analysis is to restrict a multicomponent data set to a limited, user-selected number of factors that determine the sample variance. The results obtained made it possible to identify four main factors which predetermine the chemical composition of road dust (Table 5).

Table 5. Varimax principal component loadings for PTE concentrations, $\mathrm{pH}$ and PM10 in the studied samples of road dust.

\begin{tabular}{ccccc}
\hline Elements and Parameters & PC1 & PC2 & PC3 & PC4 \\
\hline $\mathrm{V}$ & 0.61 & 0.04 & -0.04 & 0.52 \\
$\mathrm{Cr}$ & 0.78 & 0.06 & 0.23 & 0.15 \\
$\mathrm{Co}$ & 0.86 & 0.14 & -0.01 & 0.16 \\
$\mathrm{Ni}$ & 0.85 & -0.03 & -0.02 & -0.28 \\
$\mathrm{Cu}$ & 0.16 & 0.57 & 0.28 & 0.41 \\
$\mathrm{Zn}$ & 0.16 & 0.92 & 0.10 & 0.17 \\
$\mathrm{As}$ & 0.55 & 0.01 & -0.18 & 0.17 \\
$\mathrm{Cd}$ & 0.09 & 0.87 & -0.06 & 0.05 \\
$\mathrm{Sb}$ & 0.18 & 0.16 & 0.90 & -0.01 \\
$\mathrm{~Pb}$ & -0.10 & 0.05 & 0.94 & -0.01 \\
$\mathrm{pH}$ & -0.10 & -0.0 & 0.01 & -0.69 \\
$\mathrm{PM} 10$ & 0.70 & 0.073 & 0.13 & 0.12 \\
Expl. Var & 3.39 & 2.62 & 1.97 & 1.33 \\
Prp. Totl & 0.26 & 0.20 & 0.15 & 0.10 \\
\hline
\end{tabular}

The four PCs together account for $71 \%$ of the variance. The first PC explains $26 \%$ of the total variance and has a strong loading of $\mathrm{Cr}, \mathrm{Co}, \mathrm{Ni}$ and PM10. The concentrations of $\mathrm{Cr}$, Co and Ni in Surgut's road dust were generally low as compared to their world crust average values $(P I r=0.4-0.5)$. However, some sampling sites, in particular within the low-rise residential area and the power plant area, were characterized by Ni enrichment. Relatively higher concentrations of metals such as $\mathrm{Ni}$ and $\mathrm{Co}$ are caused by the adsorption of these metals by Fe-Mn colloids [87]. Both Ni and Co originate from geogenic sources. The abrasion of road surfaces is an additional source of $\mathrm{Ni}$, which is a component of asphalt bitumen and gabbro rock material [88]. High Ni contents have also been noted in gabbro rocks of the Ural Mountains [89], which are not far from Surgut.

The PC2 is dominated by $\mathrm{Zn}$ and Cd. Our observations showed that $\mathrm{Zn}$ and Cd probably originated from the same anthropogenic source. Previous studies [90-92] have reported that vehicle emissions and diesel and fossil fuel combustion are known as the primary anthropogenic sources of $\mathrm{Cd}$ and $\mathrm{Zn}$ atmospheric pollution. PC 3 is dominated by $\mathrm{Sb}$ and $\mathrm{Pb}$, accounting for $15 \%$ of the total variance. This group of elements, as shown above, is associated with traffic. $\mathrm{PC} 4$, dominated by $\mathrm{pH}$, explains $10 \%$ of the total variance. The soil acidity to a large extent predetermines the mobility of metals [65] and, therefore, their concentrations in soils. 


\subsection{Comparisons with Other Cities}

Table 6 compares the concentrations of PTEs in this study with some other world cities. Our selection of cities for such a comparison was based on the presence of comparable assemblages of the analyzed elements. A comparison allowed us to determine the geochemical properties of the road dust of Surgut as follows: low contents of As, Cd, Sb and $\mathrm{Zn}$ but a 1.6-2 times higher content of $\mathrm{Ni}$ in comparison with those in Moscow and Chelyabinsk. The high content of Ni has been previously identified in the road dust of Tyumen, which is a large city in Western Siberia [29]. The latter is explained by the fact that the road construction there involved the use of fine gravel of ultramafic and mafic rocks imported from the Urals. High concentrations of $\mathrm{Ni}$ and $\mathrm{Cr}$ are often mentioned in descriptions of Uralian ultramafic rocks such as gabbro [89]. Regarding the levels of $\mathrm{Cu}$, $\mathrm{Co}$ and $\mathrm{Cr}$ in road dust, Surgut occupies an intermediate position among other cities.

Table 6. Literature data on published metal median concentrations $\left(\mathrm{mg} \mathrm{kg}^{-1}\right)$ in street dust from cities around the world.

\begin{tabular}{ccccccccccc}
\hline City & $\mathbf{C r}$ & $\mathbf{C o}$ & $\mathbf{N i}$ & $\mathbf{C u}$ & $\mathbf{Z n}$ & $\mathbf{A s}$ & $\mathbf{C d}$ & $\mathbf{P b}$ & $\mathbf{S b}$ & $\mathbf{R e f e r e n c e}$ \\
\hline Surgut, this study & 46 & 6.9 & 41.1 & 42.8 & 89.9 & 1.3 & 0.11 & 19.0 & 0.89 & This \\
Chelyabinsk & 48.5 & 6.3 & 21.9 & 55.9 & 154 & 3.8 & 0.4 & 14.4 & 1.3 & {$[20]$} \\
Moscow & 50 & 8.0 & 26 & 93 & 252 & 2.8 & 0.61 & 53 & 4.6 & {$[23]$} \\
Alushta & 31 & 7.4 & 33 & 44 & 127 & 8.0 & 0.3 & 37 & 1.5 & {$[28]$} \\
Tyumen & 415 & 25.6 & 324 & 51.3 & 105 & 8.8 & 0.19 & 20.1 & 1.83 & {$[29]$} \\
Ahvaz, Iran & 51.5 & 9.2 & 59.7 & 74.4 & 309 & - & 0.5 & 85.4 & 2.1 & {$[93]$} \\
Hangzhou, China & 51 & 20 & 26 & 116 & 321 & - & 1.59 & 202 & - & {$[94]$} \\
Houston, TX, USA & 67 & 4.8 & 119 & 183 & 557 & - & - & 40 & - & {$[95]$} \\
Kabul, Afganistan & 38.4 & 8.52 & 66.4 & 43.6 & 122.5 & - & 1.16 & 28.7 & - & {$[96]$} \\
Kuala Lumpur, Malaysia & 74.1 & 3.36 & 11.3 & 87.0 & 314 & $\mathbf{6 8 . 8}$ & 0.71 & 98.8 & - & {$[19]$} \\
Katowice, Poland & 211 & - & 43.7 & 239 & $\mathbf{2 0 3 0}$ & - & 0.35 & $\mathbf{4 3 0}$ & - & {$[97]$} \\
Luanda, Angola & 26 & 2.9 & 10 & 42 & 317 & 5.0 & 1.1 & 351 & 3.4 & {$[98]$} \\
Nicosia, North Cyprus & 321 & - & 65 & 52 & 136 & 17.5 & - & 35.6 & - & {$[99]$} \\
Ottawa, Canada & 43.3 & 8.3 & 15.2 & 65.8 & 112 & 1.3 & 0.6 & 39 & 0.89 & {$[100]$} \\
Seul, Korea & 151 & - & - & 396 & 795 & - & - & 144 & {$[101]$} \\
Shanghai, China & 159 & - & 84 & 197 & 734 & - & 1.23 & 295 & - & {$[102]$} \\
Thessaloniki, Greece & 105 & - & 89 & $\mathbf{6 6 2}$ & 452 & - & $\mathbf{1 . 7 6}$ & 209 & - & {$[17]$} \\
Tongchuan, China & 106.5 & 31.7 & 25.3 & 32.4 & 142 & 6.7 & - & 75.2 & - & {$[103]$} \\
Toronto, Canada & 198 & - & 58.8 & 162 & 233 & - & 0.51 & 183 & -
\end{tabular}

Note: the values in bold font correspond to the highest concentration in the areas compared.

\section{Exposure and Risk Assessment}

The results of calculations of non-carcinogenic and carcinogenic risk indices through all exposure pathways (ingestion, inhalation and dermal contact) are presented in Tables 7 and 8.

Table 7. Non-carcinogenic hazard quotient $(\mathrm{HQ})$ and hazard index $(\mathrm{HI})$ values of trace elements through all exposure pathways in Surgut city.

\begin{tabular}{ccccccccc}
\hline \multirow{2}{*}{ Element } & \multicolumn{2}{c}{ HQ Ing } & \multicolumn{2}{c}{ HQ Derm } & \multicolumn{2}{c}{ HQ Inh } & \multicolumn{2}{c}{ HI } \\
\cline { 2 - 8 } & Childr & Adults & Childr & Adults & Childr & Adults & Childr & Adults \\
\hline $\mathrm{Pb}$ & $3.4 \times 10^{-2}$ & $3.8 \times 10^{-3}$ & $2.5 \times 10^{-4}$ & $2.8 \times 10^{-5}$ & $1.6 \times 10^{-4}$ & $2.7 \times 10^{-4}$ & $3.4 \times 10^{-2}$ & $3.8 \times 10^{-3}$ \\
$\mathrm{Ni}$ & $2.4 \times 10^{-2}$ & $2.7 \times 10^{-3}$ & $4.4 \times 10^{-4}$ & $4.9 \times 10^{-5}$ & $4.9 \times 10^{-2}$ & $8.1 \times 10^{-2}$ & $7.3 \times 10^{-2}$ & $8.4 \times 10^{-2}$ \\
$\mathrm{Cu}$ & $2.7 \times 10^{-2}$ & $3.1 \times 10^{-3}$ & $3.5 \times 10^{-5}$ & $4.0 \times 10^{-6}$ & $3.2 \times 10^{-5}$ & $5.4 \times 10^{-5}$ & $2.7 \times 10^{-2}$ & $3.1 \times 10^{-3}$ \\
$\mathrm{Zn}$ & $1.9 \times 10^{-3}$ & $2.2 \times 10^{-4}$ & $1.4 \times 10^{-5}$ & $1.6 \times 10^{-6}$ & $4.5 \times 10^{-5}$ & $7.6 \times 10^{-5}$ & $1.9 \times 10^{-3}$ & $2.2 \times 10^{-4}$ \\
$\mathrm{As}$ & $2.7 \times 10^{-2}$ & $3.1 \times 10^{-3}$ & $2.1 \times 10^{-5}$ & $2.4 \times 10^{-6}$ & $9.1 \times 10^{-5}$ & $1.5 \times 10^{-4}$ & $2.8 \times 10^{-2}$ & $3.2 \times 10^{-3}$ \\
$\mathrm{Cd}$ & $6.9 \times 10^{-4}$ & $7.7 \times 10^{-5}$ & $2.0 \times 10^{-5}$ & $2.3 \times 10^{-6}$ & $1.1 \times 10^{-3}$ & $1.9 \times 10^{-3}$ & $1.8 \times 10^{-3}$ & $2.0 \times 10^{-3}$ \\
$\mathrm{Sb}$ & $1.4 \times 10^{-2}$ & $1.6 \times 10^{-3}$ & $7.0 \times 10^{-5}$ & $7.9 \times 10^{-6}$ & $3.2 \times 10^{-4}$ & $5.3 \times 10^{-4}$ & $1.5 \times 10^{-2}$ & $2.1 \times 10^{-3}$ \\
\hline
\end{tabular}


Table 8. Carcinogenic risk (CRA) values of $\mathrm{Pb}$ and As through all exposure pathways in Surgut city.

\begin{tabular}{ccccccccc}
\hline \multirow{2}{*}{ Element } & \multicolumn{2}{c}{ CRA Ing } & \multicolumn{2}{c}{ CRA Derm } & \multicolumn{2}{c}{ CRA Inh } & \multicolumn{2}{c}{ CRA Sum } \\
\cline { 2 - 8 } & Childr & Adults & Childr & Adults & Childr & Adults & Childr & Adults \\
\hline $\mathrm{Pb}$ & $1.0 \times 10^{-6}$ & $1.2 \times 10^{-6}$ & $7.6 \times 10^{-9}$ & $8.5 \times 10^{-10}$ & $2.4 \times 10^{-8}$ & $4.0 \times 10^{-8}$ & $1.1 \times 10^{-6}$ & $1.6 \times 10^{-7}$ \\
$\mathrm{As}$ & $1.2 \times 10^{-5}$ & $1.4 \times 10^{-6}$ & $9.5 \times 10^{-9}$ & $1.1 \times 10^{-9}$ & $5.9 \times 10^{-7}$ & $9.8 \times 10^{-7}$ & $1.3 \times 10^{-5}$ & $2.4 \times 10^{-6}$ \\
\hline
\end{tabular}

The non-carcinogenic risk assessment was based on metal concentrations, which were above their Clarke (world crust average) values (PIr $>1$ ). The results showed that noncarcinogenic risk in Surgut was mainly associated with the ingestion of dust particles. Data from other cities confirm that ingestion is the most hazardous pathway $[21,40,96,98,105]$. Children tend to be at higher risk than adults, because their relatively lower body weight implies that the impact of road dust contaminated with heavy metals can be relatively higher. The obtained $\mathrm{HI}$ values show that $\mathrm{Sb}, \mathrm{Ni}, \mathrm{Cu}$ and $\mathrm{As}$ are generally the most harmful elements within Surgut, with additional health risks associated with $\mathrm{Cd}$ and $\mathrm{Pb}$ within some areas of the city. It should be noted that despite the low Ni enrichment of road dust, its health risk is high due to the high toxicity of this element.

The carcinogenic risks of $\mathrm{As}$ and $\mathrm{Pb}$ were also mainly associated with the ingestion pathway, whereas the risks from dermal contact are very low. The total carcinogenic risk values (CRA sum, see Table 8) ranged from $10^{-5}$ to $10^{-7}$. According to the U.S. EPA, any value of cancer risk within the range of $10^{-6}$ to $10^{-4}$ is an acceptable or tolerable risk, and any value below $10^{-6}$ can be ignored. Therefore, the present study showed that carcinogenic risks from the PTEs in the road dust of Surgut were insignificant due to their low concentrations.

\section{Conclusions}

The road dust of Surgut, as in the majority of cities of the world, has an alkaline reaction due to the presence of carbonate microparticles. The 100-250 $\mu \mathrm{m}$ fraction, which was predominant in the particle size distribution of the studied dust samples, originates from geogenic sources and abrasion processes caused by road traffic. Fine particles $(<50 \mu \mathrm{m})$, which mainly originate from industrial emissions, had a mean content of $17.5 \%$ in the studied samples. Therefore, the composition of road dust was mainly predetermined by contributions from sources associated with road traffic and soil erosion. The texture of Surgut's road dust is relatively homogeneous. Fluctuations in the particle size distribution for roads of different categories and different land use areas are small.

It was found that Surgut's road dust was rich in $\mathrm{Sb}, \mathrm{Cu}, \mathrm{Zn}, \mathrm{Cd}$ and $\mathrm{Pb}$ as compared to their mean contents in the upper part of the Earth's crust. These elements are regarded as typical urban pollutants that accumulate in the road dust of many cities. Those element concentrations in the road dust of Surgut increased by multiples of 1.4-2.8 on average with increasing traffic densities. The highest concentrations were found within stretches of roads, where traffic jams regularly occur. The main source of these elements is from the abrasion of car tires and brake pads. In addition to traffic densities, the road dust composition was influenced by solid waste incineration, which led to the $\mathrm{Cd}$ and $\mathrm{Zn}$ contamination of the studied samples.

Based on the values of the total potential eco-logical risk index (PI) and the total enrichment factor $(Z e)$, levels of the total contamination of Surgut's road dust were mostly low. The moderate contamination levels were only detected in samples from high-traffic roads. The generally low contamination can be explained by the predominance of coarse particles in the road dust. Taking into account that the PTE concentrations in fine fractions (PM10) is significantly higher than in the coarse fraction, further research should focus on the analysis of the fine fraction.

The present study on PTEs showed that their greatest potential risks to human health were associated with the ingestion pathway; however, both carcinogenic and non- 
carcinogenic risks of such PTEs were generally acceptable or tolerable due to their low concentrations in the road dust of Surgut.

The results obtained in this study can be used in the planning and further development of the transport network of Surgut city and also help improve the efficiency of the street cleaning practices by the municipal services.

Supplementary Materials: The following are available online at https:/ / www.mdpi.com/article/ 10.3390/atmos13010030/s1, Table S1: Description of sampling sites, Table S2: Methods of analysis, analytical results and recovery of certified reference material, Table S3: Exposure parameters used for the health risk assessment.

Author Contributions: D.M.: conceptualization, original draft writing; R.P.: sample collection, data processing; A.S.: conceptualization, visualization, reviewing the manuscript; V.T. sample collection, reviewing the manuscript. All authors have read and agreed to the published version of the manuscript.

Funding: This research was funded by the Russian Foundation for Basic Research (project no. 19-0550062) and project no. 121041600045-8 of RAS Siberian Branch.

Institutional Review Board Statement: Not applicable.

Informed Consent Statement: Not applicable.

Data Availability Statement: The datasets generated during and/or analyzed during the current study are available from the corresponding author on reasonable request.

Acknowledgments: We would like to thank the Russian Foundation for Basic Research for the financial support (19-05-50062). The authors are especially grateful to Vasiliy Karandashev for the element determination.

Conflicts of Interest: The authors declare no conflict of interest.

\section{References}

1. Sutherland, R. Bed sediment-associated trace metals in an urban stream, Oahu, Hawaii. Environ. Geol. 2000, 39, 611-627. [CrossRef]

2. Chow, J.; Watson, J.; Lu, Z. Descriptive analysis of $\mathrm{PM}(2.5)$ and $\mathrm{PM}(10)$ at regionally representative locations during SJVAQS/AUSPEX 1996. Atmos. Environ. 1996, 30, 2079-2112. [CrossRef]

3. Kupiainen, K. Monograph of Boreal Environment Research. In Road Dust from Pavement Wear and Traction Sanding; Finnish Environment Institute: Helsinki, Finland, 2007; 50p, Available online: http://hdl.handle.net/10138/39334 (accessed on 18 November 2021).

4. Mazzei, F.; D’alessandro, A.; Lucarelli, F.; Nava, S.; Prati, P.; Valli, G.; Vecchi, R. Characterization of particulate matter sources in an urban environment. Sci. Total Environ. 2008, 401, 81-89. [CrossRef]

5. Kosheleva, N.E.; Vlasov, D.V.; Korlyakov, I.D.; Kasimov, N.S. Contamination of urban soils with heavy metals in Moscow as affected by building development. Sci. Total Environ. 2018, 636, 854-863. [CrossRef] [PubMed]

6. Varrica, D.; Dongarra, G.; Sabatino, G.; Monna, F. Inorganic geochemistry of roadway dust from the metropolitan area of Palermo, Italy. Environ. Geol. 2003, 44, 222-230. [CrossRef]

7. Amato, F.; Pandolfi, M.; Viana, M.; Querol, X.; Alastuey, A.; Moreno, T. Spatial and chemical patterns of PM10 in road dust deposited in urban environment. Atmos. Environ. 2009, 43, 1650-1659. [CrossRef]

8. Amato, F.; Cassee, F.R.; Denier van der Gon, H.A.C.; Gehrig, R.; Gustafsson, M.; Hafner, W.; Harrison, R.M.; Jozwicka, M.; Kelly, F.J.; Moreno, T.; et al. Urban air quality: The challenge of traffic non-exhaust emissions. J. Hazard. Mater. 2014, 275, 31-36. [CrossRef]

9. Denier van der Gon, H.A.C.; Gerlofs-Nijland, M.E.; Gehrig, R.; Gustafsson, M.; Janssen, N.; Harrison, R.M.; Hulskotte, J.; Johansson, C.; Jozwicka, M.; Keuken, M.; et al. The policy relevance of wear emissions from road transport, now and in the future-An international workshop report and consensus statement. J. Air Waste Manag. 2013, 63, 136-149. [CrossRef]

10. Murakami, M.; Nakajima, F.; Furumai, H.; Tomiyasu, B.; Owari, M. Identification of particles containing chromium and lead in road dust and soakaway sediment by electron probe microanalyser. Chemosphere 2007, 67, 2000-2010. [CrossRef] [PubMed]

11. Irvine, K.N.; Perrelli, M.F.; Ngoen-klan, R.; Droppo, I.G. Metal levels in street sediment from an industrial city: Spatial trends, chemical fractionation, and management implications. J. Soils Sedim. 2009, 9, 328-341. [CrossRef]

12. Nazzal, Y.; Rosen, M.A.; Al-Rawabden, A.M. Assessment of metal pollution in urban road dusts from selected highways of the Greater Toronto Area in Canada. Environ. Monit. Assess. 2013, 185, 1847-1858. [CrossRef] [PubMed] 
13. Vlasov, D.V.; Kosheleva, N.E.; Kasimov, N.S. Spatial distribution and sources of potentially toxic elements in road dust and its PM10 fraction of Moscow megacity. Sci. Total Environ. 2021, 761, 143267. [CrossRef] [PubMed]

14. Tager, I.B. Health effects of aerosols: Mechanisms and epidemiology. In Aerosols Handbook: Measurement, Dosimetry, and Health Effects; Ruzer, L.S., Harley, N.H., Eds.; CRC Press: Boca Raton, FA, USA, 2005; pp. 619-696.

15. Jose, J.; Srimuruganandam, B. Investigation of road dust characteristics and its associated health risks from an urban environment. Environ. Geochem. Health 2020, 42, 2819-2840. [CrossRef]

16. Demographics. Federal State Statistics Service. 2021. Available online: https://rosstat.gov.ru/folder/12781 (accessed on 18 November 2021).

17. Li, F.; Zhang, J.; Huang, J.; Huang, D.; Yang, J.; Song, Y.; Zeng, G. Heavy metals in road dust from Xiandao District, Changsha City, China: Characteristics, health risk assessment, and integrated source identification. Environ. Sci. Pollut. Res. 2016, 23, 13100-13113. [CrossRef] [PubMed]

18. Gulia, S.; Goyal, P.; Goyal, S.K.; Kumar, R. Re-suspension of road dust: Contribution, assessment and control through dust suppressants-A review. Int. J. Environ. Sci. Technol. 2019, 16, 1717-1728. [CrossRef]

19. Othman, M.; Latif, M.T. Pollution characteristics, sources, and health risk assessments of urban road dust in Kuala Lumpur City. Environ. Sci. Pollut. Res. 2020, 27, 11227-11245. [CrossRef]

20. Kasimov, N.S.; Bityukova, V.R.; Malkhazova, S.M.; Kosheleva, N.E.; Nikiforova, E.M.; Shartova, N.V.; Vlasov, D.V.; Timonin, S.A.; Krainov, V.N. Regions and Cities of RUSSIA: The Integrated Assessment of the Environment; Filimonov MV Publishing: Moscow, Russia, 2014; 560p. (In Russian)

21. Krupnova, T.G.; Rakova, O.V.; Gavrilkina, S.V.; Antoshkina, E.G.; Baranov, E.O.; Yakimova, O.N. Road dust trace elements contamination, sources, dispersed composition, and human health risk in Chelyabinsk, Russia. Chemosphere 2020, $261,127799$. [CrossRef]

22. Ladonin, D.V.; Plyaskina, O.V. Isotopic composition of lead in soils and street dust in the Southeastern administrative district of Moscow. Eurasian Soil Sci. 2009, 42, 93-104. [CrossRef]

23. Ladonin, D.V.; Mikhaylova, A.P. Heavy Metals and Arsenic in Soils and Street Dust of the Southeastern Administrative District of Moscow: Long-Term Data. Eurasian Soil Sci. 2020, 53, 1635-1644. [CrossRef]

24. Vlasov, D.V.; Kasimov, N.S.; Kosheleva, N.E. Geochemistry of the road dust in the Eastern district of Moscow. Vestn. Mosk. Univ. Geogr. 2015, 1, 23-33. (In Russian)

25. Kasimov, N.S.; Vlasov, D.V.; Kosheleva, N.E.; Nikiforova, E.M. Geochemistry of Landscapes of Eastern Moscow; APR Publishing: Moscow, Russia, 2016; 276p. (In Russian)

26. Kasimov, N.S.; Vlasov, D.V.; Kosheleva, N.E. Enrichment of road dust particles and adjacent environments with metals and metalloids in eastern Moscow. Urban Clim. 2020, 32, 100638. [CrossRef]

27. Kaygorodov, R.V.; Tiunova, M.I.; Druzshinina, A.A. Polluting substances in a dust of travellers of parts and in wood vegetation of roadside strips of a city zone. Vestn. Permsk. Univ. Seriya Biol. 2009, 10, 141-146. (In Russian)

28. Kasimov, N.S.; Bezberdaya, L.A.; Vlasov, D.V.; Lychagin, M.Y. Metals, Metalloids, and benzo[a]pyrene in PM10 particles of soils and road dust of Alushta City. Eurasian Soil Sci. 2019, 52, 1608-1621. [CrossRef]

29. Konstantinova, E.; Minkina, T.; Konstantinov, A.; Sushkova, S.; Antonenko, E.; Kurasova, A.; Loiko, S. Pollution status and human health risk assessment of potentially toxic elements and polycyclic aromatic hydrocarbons in urban street dust of Tyumen city, Russia. Environ. Geochem. Health 2020. [CrossRef] [PubMed]

30. Program for the Integrated Development of the Transport Infrastructure of the Municipal Formation "Urban District of the City of Surgut" for the Period up to 2035. 2017. Available online: https:/ /www.dumasurgut.ru/getattachment/2be92a61-ce22-4fec-97 0b-ac2456e2a195/221-VI\%20\%D0\%94\%D0\%93.aspx (accessed on 18 November 2021).

31. Vinokurova, M.V.; Vinokurov, M.V.; Voronin, S.A. Effect of auto-road complex in the city of Surgut on air pollution and population health. Gig. Sanit. 2015, 94, 57-61. (In Russian)

32. Reference Book on the USSR Climate. Series 2. Issue 17. Tyumen and Omsk Regions; Gidrometeoizdat: S.-Petersburg, Russia, 1998; 702p. (In Russian)

33. Nasratinova, R.M.; Shantarin, V.D. Ecological monitoring of snow cover in the Town of Surgut. Oil Gas 2014, 6, 120-123. (In Russian)

34. Gorban, M.V.; Nakonechniy, N.V.; Vdovkin, R.S.; Bashkatova, Y.V. The condition assessment of Surgut City soils experiencing the influence of motor transport. Vestn. KrasGAU 2014, 9, 53-58. (In Russian)

35. Samoylenko, Z.A.; Bezuglaya, V.V.; Guselnikova, M.V.; Pyatova, P.N. Content of heavy metals in soils under the influence of unauthorized dumps in Surgut. J. Agric. Environ. 2021, 3, 1-6. (In Russian)

36. Slashcheva, A.V. Ecological and geochemical assessment of the Surgut lowland territory. Reg. Environ. Issues 2011, 3, 35-44. (In Russian)

37. Moskovchenko, D.V. Ecogeochemistry of Oil and Gas Producing Regions of Western Siberia; Academic Publishing House "Geo": Novosibirsk, Russia, 2013; 259p. (In Russian)

38. Bourliva, A.; Christophoridis, C.; Papadopoulou, L.; Giouri, K.; Papadopoulos, A.; Mitsika, E.; Fytianos, K. Characterization, Heavy metal content and health risk assessment of urban road dusts from the historic center of the city of Thessaloniki, Greece. Environ. Geochem. Health 2017, 39, 611-634. [CrossRef] [PubMed] 
39. Alsbou, E.; Zaitoun, M.A.; Alasoufi, A.M.; Al Shra'Ah, A. Concentration and Source Assessment of Polycyclic Aromatic Hydrocarbons in the Street Soil of Ma'an City, Jordan. Arch. Environ. Contam. Toxicol. 2019, 77, 619-630. [CrossRef] [PubMed]

40. Alsohaimi, I.H.; El-Hashemy, M.A.; Al-Ruwaili, A.G.; El-Nasr, T.A.S.; Almuaikel, N.S. Assessment of Trace Elements in Urban Road Dust of a City in a Border Province Concerning Their Levels, Sources, and Related Health Risks. Arch. Environ. Contam. Toxicol. 2020, 79, 23-38. [CrossRef]

41. Padoan, E.; Romè, C.; Ajmone-Marsan, F. Bioaccessibility and size distribution of metals in road dust and roadside soils along a peri-urban transect. Sci. Total Environ. 2017, 601, 89-98. [CrossRef]

42. Trujillo-Gonzalez, J.M.; Torres-Mora, M.A.; Keesstra, S.; Brevik, E.C.; Jimenez-Ballesta, R. Heavy metal accumulation related to population density in road dust samples taken from urban sites under different land uses. Sci. Total Environ. 2016, 553, 636-642. [CrossRef] [PubMed]

43. Al-Awadhi, J.M.; AlShuaibi, A.A. Dust fallout in Kuwait City: Deposition and characterization. Sci. Total Environ. 2013, 461, 139-148. [CrossRef]

44. Li, F.; Huang, J.; Zeng, G.; Huang, X.; Liu, W.; Wu, H.; Yuan, Y.; He, X.; Lai, M. Spatial distribution and health risk assessment of toxic metals associated with receptor population density in street dust: A case study of Xiandao District, Changsha, Middle China. Environ. Sci. Pollut. Res. 2015, 22, 6732-6742. [CrossRef]

45. Kara, M.; Dumanoglu, Y.; Altiok, H.; Elbir, T.; Odabasi, M.; Bayram, A. Seasonal and spatial variations of atmospheric trace elemental deposition in the Aliaga industrial region, Turkey. Atmos. Res. 2014, 149, 204-216. [CrossRef]

46. Bourennane, H.; Douay, F.; Sterckeman, T.; Villanneau, E.; Ciesielski, H.; King, D.; Baize, D. Mapping of anthropogenic trace elements inputs in agricultural topsoil from Northern France using enrichment factors. Geoderma 2010, 157, 165-174. [CrossRef]

47. Syso, A.I. Patterns of Distribution of Chemical Elements in Soil-Forming Rocks and Soils of Western Siberia; Publishing House of SB RAS: Novosibirsk, Russia, 2007; 227p. (In Russian)

48. Moskovchenko, D.V. Oil and Gas Production and the Environment: Ecological and Geochemical Analysis of the Tyumen Region; Nauka, Sib.predpriyatie RAS: Novosibirsk, Russia, 1998; 112p. (In Russian)

49. Rudnick, R.L.; Gao, S. Composition of the continental crust. In Treatise on Geochemistry, 3rd ed.; Elsevier Science: New York, NY, USA, 2003; pp. 1-64.

50. Hakanson, L. An ecological risk index for aquatic pollution control. A sedimentological approach. Water Res. 1980, 14, 975-1001. [CrossRef]

51. Zhang, X.; Wang, Y.; Guo, S.; Li, H.; Liu, J.; Zhang, Z.; Yan, L.; Tan, C.; Yang, Z.; Guo, X. Concentration and speciation of trace metals and metalloids from road-deposited sediments in urban and rural areas of Beijing, China. J. Soils Sediments 2020, 20, 3487-3501. [CrossRef]

52. Yongming, H.; Peixuan, D.; Junji, C.; Posmentier, E.S. Multivariate analysis of heavy metal contamination in urban dusts of Xi'an, Central China. Sci. Total Environ. 2006, 355, 176-186. [CrossRef]

53. US EPA (US Environmental Protection Agency). Risk Assessment Guidance for Superfund. Volume I: Human Health Evaluation Manual (Part A). Interim Final (EPA/ 540/1-89/002); Office of Emergency and Remedial Response: Washington, DC, USA, 1989.

54. Kong, S.; Lu, B.; Bai, Z.; Zhao, X.; Chen, L.; Han, B.; Li, Z.; Ji, Y.; Xu, Y.; Liu, Y.; et al. Potential threat of heavy metals in re-suspended dusts on building surfaces in oilfeld city. Atmos. Environ. 2011, 25, 4192-4204. [CrossRef]

55. Zheng, N.; Liu, J.; Wang, Q.; Liang, Z. Health risk assessment of heavy metal exposure to street dust in the zinc smelting district, Northeast of China. Sci. Total Environ. 2010, 408, 726-733. [CrossRef]

56. Li, R.P.; Cai, G.Q.; Wang, J.; Wei, O.Y.; Cheng, H.G.; Lin, C.Y. Contents and chemical forms of heavy metals in school and roadside topsoils and road-surface dust of Beijing. J. Soils Sediments 2014, 14, 1806-1817. [CrossRef]

57. Al-Khashman, O.A. The investigation of metal concentrations in street dust samples in Aqaba city, Jordan. Environ. Geochem. Health 2007, 29, 197-207. [CrossRef] [PubMed]

58. Acosta, J.A.; Faz, A.; Kalbitz, K.; Jansen, B.; Martínez-Martínez, S. Heavy metal concentrations in particle size fractions from street dust of Murcia (Spain) as the basis for risk assessment. J. Environ. Monit. 2011, 13, 3087-3096. [CrossRef] [PubMed]

59. Li, X.; Zhang, Y.; Luo, J.; Wang, T.; Lian, H.; Ding, Z. Bioaccessibility and health risk of arsenic, mercury and other metals in urban street dusts from a mega-city, Nanjing, China. Environ. Pollut. 2011, 159, 1215-1221. [CrossRef]

60. Robertson, D.J.; Taylor, K.G.; Hoon, S.R. Geochemical and mineral magnetic characterisation of urban sediment particulates, Manchester, UK. Appl. Geochem. 2003, 18, 269-282. [CrossRef]

61. Christoforidis, A.; Stamatis, N. Heavy metal contamination in street dust and roadside soil along the major national road in Kavala's region, Greece. Geoderma 2009, 15, 257-263. [CrossRef]

62. Zaytseva, N.V.; May, I.V.; Maks, A.A.; Zagorodnov, S.Y. Analysis of the dispersion and component composition of the dust for the assessment of the exposure to the population in the areas of influence of industrial emissions of stationary source. Hyg. Sanit. 2013, 5, 19-23. (In Russian)

63. Lanzerstorfer, C. Heavy metals in the finest size fractions of road-deposited sediments. Environ. Pollut. 2018, $239,522-531$. [CrossRef] [PubMed]

64. Cowan, N.; Blair, D.; Malcolm, H.; Graham, M. A survey of heavy metal contents of rural and urban roadside dusts: Comparisons at low, medium and high traffic sites in Central Scotland. Environ. Sci. Pollut. Res. 2021, 28, 7365-7378. [CrossRef]

65. Kabata-Pendias, A. Trace Elements in Soils and Plants, 3rd ed.; CRC press: Boca Raton, FL, USA, 2000; 432p. [CrossRef] 
66. De Miguel, E.; Llamas, J.F.; Chacón, E.; Berg, T.; Larssen, S.; Røyset, O.; Vadset, M. Origin and patterns of distribution of trace elements in street dust: Unleaded petrol and urban lead. Atmos. Environ. 1997, 31, 2733-2740. [CrossRef]

67. Shi, G.; Chen, Z.; Bi, C.; Wang, L.; Teng, J.; Li, Y.; Xu, S. A comparative study of health risk of potentially toxic metals in urban and suburban road dust in the most populated city of China. Atmos. Environ. 2011, 45, 764-771. [CrossRef]

68. Siddiqui, Z.; Khillare, P.S.; Jyethi, D.S.; Aithani, D.; Yadav, A.K. Pollution characteristics and human health risk from trace metals in roadside soil and road dust around major urban parks in Delhi city. Air Qual. Atmos. Health 2020, 13, 1271-1286. [CrossRef]

69. Opekunova, M.G.; Opekunov, A.Y.; Kukushkin, S.Y.; Ganul, A.G. Background contents of heavy metals in soils and bottom sediments in the north of Western Siberia. Eurasian Soil Sci. 2019, 52, 380-395. [CrossRef]

70. Yuan, G.L.; Sun, T.H.; Han, P.; Li, J.; Lang, X.X. Source identification and ecological risk assessment of heavy metals in topsoil using environmental geochemical mapping: Typical urban renewal area in Beijing, China. J. Geochem. Explor. 2014, 136, 40-47. [CrossRef]

71. Cao, Z.; Chen, Q.; Wang, X.; Zhang, Y.; Wang, S.; Wang, M.; Zhao, L.; Yan, G.; Zhang, X.; Zhang, Z.; et al. Contamination characteristics of trace metals in dust from different levels of roads of a heavily air-polluted city in north China. Environ. Geochem. Health 2018, 40, 2441-2452. [CrossRef] [PubMed]

72. Shevchenko, V.P.; Pokrovsky, O.S.; Vorobyev, S.; Krickov, I.V.; Manasypov, R.M.; Politova, N.V.; Kopysov, S.G.; Dara, O.M.; Auda, Y.; Shirokova, L.S.; et al. Impact of snow deposition on major and trace element concentrations and elementary fluxes in surface waters of the Western Siberian Lowland across a $1700 \mathrm{~km}$ latitudinal gradient. Hydrol. Earth Syst. Sci. 2017, 21, 5725-5746. [CrossRef]

73. Pavlov, D.; Dakhouche, A.; Rogachev, T. Influence of arsenic, antimony and bismuth on the properties of lead/acid battery positive plates. J. Power Sources 1990, 1, 117-129. [CrossRef]

74. Nriagu, J.O.; Pacyna, J.M. Quantitative assessment of worldwide contamination of air, water and soils by trace metals. Nat. Cell Biol. 1988, 333, 134-139. [CrossRef]

75. Mugica-Alvarez, V.; Maubert, M.; Torres-Rodríguez, M.; Muñoz, J.; Rico, E. Temporal and spatial variations of metal content in TSP and PM10 in Mexico City during 1996. J. Aerosol Sci. 2002, 33, 91-102. [CrossRef]

76. Napier, F.; D'Arcy, B.; Jefferies, C. A review of vehicle related metals and polycyclic aromatic hydrocarbons in the UK environment. Desalination 2008, 226, 143-150. [CrossRef]

77. Adachi, K.; Tainosho, Y. Characterization of heavy metal particles embedded in tire dust. Environ. Int. 2004, 30, 1009-1017. [CrossRef] [PubMed]

78. Mummullage, S.; Egodawatta, P.; Ayoko, G.A.; Goonetilleke, A. Use of physicochemical signatures to assess the sources of metals in urban road dust. Sci. Total Environ. 2015, 541, 1303-1309. [CrossRef] [PubMed]

79. Miazgowicz, A.; Krennhuber, K.; Lanzerstorfer, C. Metals concentrations in road dust from high traffic and low traffic area: A size dependent comparison. Int. J. Environ. Sci. Technol. 2020, 17, 3365-3372. [CrossRef]

80. Councell, T.B.; Duckenfield, K.U.; Landa, E.R.; Callender, E. Tire wear particles as a source of zinc to the environment. Environ. Sc. Technol. 2004, 38, 4206-4214. [CrossRef] [PubMed]

81. Hjortenkrans, D.; Bergbäck, B.; Häggerud, A. New metal emission patterns in road traffic environments. Environ. Monit. Assess. 2006, 117, 85-98. [CrossRef] [PubMed]

82. Dall'Osto, M.; Beddows, D.C.; Gietl, J.K.; Olatunbosun, O.A.; Yang, X.; Harrison, R.M. Characteristics of tyre dust in polluted air: Studies by single particle mass spectrometry (ATOFMS). Atmos. Environ. 2014, 94, 224-230. [CrossRef]

83. Nriagu, J.O. A History of Global Metal Pollution. Science 1996, 272, 223. [CrossRef]

84. Davis, A.P.; Shokouhian, M.; Ni, S. Loading estimates of lead, copper, cadmium, and zinc in urban runoff from specific sources. Chemosphere 2001, 44, 997-1009. [CrossRef]

85. Thorpe, A.; Harrison, R.M. Sources and properties of non-exhaust particulate matter from road traffic: A review. Sci. Total Environ 2008, 400, 270-282. [CrossRef]

86. Bityukova, V.R.; Mozgunov, N.A. Spatial Features transformation of emission from motor vehicles in Moscow. Geogr. Environ. Sustain. 2019, 12, 57-73. [CrossRef]

87. Al-Khashman, O.A. Assessment of heavy metals contamination in deposited street dusts in different urbanized areas in the city of Ma'an, Jordan. Environ. Earth Sci. 2013, 70, 2603-2612. [CrossRef]

88. Lindgren, A. Asphalt Wear and Pollution Transport. Sci. Total Environ. 1996, 189, 281-286. [CrossRef]

89. Lesovaya, S.N.; Goryachkin, S.V.; Polekhovskii, Y.S. Soil formation and weathering on ultramafic rocks in the mountainous tundra of the Rai-Iz massif, Polar Urals. Eurasian Soil Sci. 2012, 45, 33-44. [CrossRef]

90. Aminiyan, M.M.; Baalousha, M.; Mousavi, R.; Aminiyan, F.M.; Hosseini, H.; Heydariyan, A. The ecological risk, Source identification, and pollution assessment of heavy metals in road dust: A case study in Rafsanjan, SE Iran. Environ. Sci. Pollut. Res. 2018, 25, 13382-13395. [CrossRef] [PubMed]

91. Kabata-Pendias, A.; Mukherjee, A.B. Trace Elements from Soil to Human; Springer: Berlin/Heidelberg, Germany, 2007; 550p.

92. Wei, B.; Jiang, F.; Li, X.; Mu, S. Spatial distribution and contamination assessment of heavy metals in urban road dusts from Urumqi, NW China. Microchem. J. 2009, 93, 147-152. [CrossRef]

93. Najmeddin, A.; Keshavarzi, B.; Moore, F.; Lahijanzadeh, A. Source apportionment and health risk assessment of potentially toxic elements in road dust from urban industrial areas of Ahvaz megacity, Iran. Environ. Geochem. Health 2018, 40, 1187-1208. [CrossRef] [PubMed] 
94. Zhang, M.K.; Wang, H. Concentrations and chemical forms of potentially toxic metals in road-deposited sediments from different zones of Hangzhou, China. J. Environ. Sci. 2009, 21, 625-631. [CrossRef]

95. Fiala, M.; Hwang, H.M. Influence of Highway Pavement on Metals in Road Dust: A Case Study in Houston, Texas. Water Air Soil Pollut. 2021, 232, 185. [CrossRef]

96. Jadoon, W.; Khpalwak, W.; Chidya, R.C.G.; Abdel-Dayem, S.M.M.A.; Takeda, K.; Makhdoom, M.A.; Sakugawa, H. Evaluation of Levels, Sources and Health Hazards of Road-Dust Associated Toxic Metals in Jalalabad and Kabul Cities, Afghanistan. Arch. Environ. Contam. Toxicol. 2018, 74, 32-45. [CrossRef] [PubMed]

97. Adamiec, E.; Jarosz-Krzemińska, E.; Wieszała, R. Heavy metals from non-exhaust vehicle emissions in urban and motorway road dusts. Environ. Monit. Assess. 2016, 188, 369. [CrossRef]

98. Ferreira-Baptista, L.; De Miguel, E. Geochemistry and risk assessment of street dust in Luanda, Angola: A tropical urban environment. Atmos. Environ. 2005, 39, 4501-4512. [CrossRef]

99. Musa, A.A.; Hamza, S.M.; Kidak, R. Street dust heavy metal pollution implication on human health in Nicosia, North Cyprus Environ. Sci. Pollut. Res. 2019, 26, 28993-29002. [CrossRef]

100. Rasmussen, P.; Subramanian, K.; Jessiman, B. A multi-element profile of house dust in relation to exterior dust and soils in the city of Ottawa, Canada. Sci. Total Environ. 2001, 267, 125-140. [CrossRef]

101. Kim, W.; Doh, S.J.; Park, Y.H.; Yun, S.T. Two-year magnetic monitoring in conjunction with geochemical and electron microscopic data of roadside dust in Seoul, Korea. Atmos. Environ. 2007, 41, 7627-7641. [CrossRef]

102. Shi, G.; Chen, Z.; Xu, S.; Zhang, J.; Wang, L.; Bi, C.; Teng, J. Potentially toxic metal contamination of urban soils and roadside dust in Shanghai, China. Environ. Pollut. 2008, 156, 251-260. [CrossRef]

103. Zhang, M.; Lu, X.; Chen, H.; Gao, P.; Fu, Y. Multi-element characterization and source identification of trace metal in road dust from an industrial city in semi-humid area of Northwest China. J. Radioanal. Nucl. Chem. 2015, 303, 637-646. [CrossRef]

104. Pan, H.; Lu, X.; Lei, K. A comprehensive analysis of heavy metals in urban road dust of Xi'an, China: Contamination, source apportionment and spatial distribution. Sci. Total Environ. 2017, 609, 1361-1369. [CrossRef]

105. Li, H.; Qian, X.; Hu, W.; Wang, Y.; Gao, H. Chemical speciation and human health risk of trace metals in urban street dusts from a metropolitan city, Nanjing, SE China. Sci. Total Environ. 2013, 456, 212-221. [CrossRef] [PubMed] 